\title{
TOXIC INCOME AS A TRIGGER OF CLIMATE CHANGE
}

\author{
FANDER FALCON $\mathbf{1}^{1,2, *}$
}

RAFAEL BURBANO 3

JESUS RAMOS-MARTIN ${ }^{4}$

\section{PEDRO CANGO ${ }^{1}$}

Recibido: 12 de abril

Aceptado: 1 de mayo

\section{${ }^{*}$ Correspondence: ffalconi@flacso.edu.ec}

${ }^{1}$ Departamento de Desarrollo, Ambiente y Territorio, Facultad Latinoamericana de Ciencias Sociales (FLACSO), La Pradera E7-174 y Diego de Almagro, Quito 170518, Ecuador; pedro.cango@gmail.com

2 Universidad Nacional de Educación (UNAE), Parroquia Javier Loyola Azogues, Cañar 030154, Ecuador.

${ }^{3}$ Departamento de Economía Cuantitativa, Escuela Politécnica Nacional, Ladrón de Guevara E11-253, Quito 170517, Ecuador; rafael.burbano@epn.edu.ec

${ }^{4}$ Grupo de Población y Ambiente, Universidad Regional Amazónica Ikiam, Vía Muyuna-Atacapi, Km. 7, Tena 150102, Ecuador; jesus.ramos@ikiam.edu.ec 



\title{
TOXIC INCOME AS A TRIGGER OF CLIMATE CHANGE ${ }^{1}$
}

Fander Falconí, Rafael Burbano, Jesus Ramos-Martin, Pedro Cango

Keywords: climate change; CO2 emissions; toxic income; contraction and convergence; Paris agreement; intended nationally determined contributions

(INDC)

\begin{abstract}
The rate of $\mathrm{CO}_{2}$ emissions concentration in the atmosphere increases the likelihood of significant impacts on humankind and ecosystems. The assumption that permissible levels of greenhouse gas emissions cannot exceed the global average temperature increase of $2{ }^{\circ} \mathrm{C}$ in relation to pre-industrial levels remains uncertain. Despite this uncertainty, the direct implication is that enormous quantities of fossil fuels have, thusfar, wronglybeen countedasassets by hydrocarbon firms as they cannot be exploited if we want to keep climate under certain control. These are the socalled "toxic assets". Due to the relation-

ship among $\mathrm{CO}_{2}$ emissions, GDP, energy consumption, and energy efficiency, the concept of toxic assets can be transferred to toxic income, which is the income level that would generate levels of $\mathrm{CO}_{2}$ emissions incompatible with keeping climate change under control. This research, using a simulation model based on country-based econometric models, estimated a threshold for income per capita above which the temperature limit of $2{ }^{\circ} \mathrm{C}$ would be surpassed. Under the business as usual scenario, average per capita income would be $\$ 14,208$ (in constant 2010 USD) in 2033; and under the intervention scenario, which reflects
\end{abstract}

i Publicado en Sustainability 2019, 11 (8), 2448

Recuperado de https://www.mdpi.com/2071-1050/11/8/2448 
the commitments of the COP21 meeting held in Paris in December 2015, the toxic revenue would be $\$ 13,433$ (in constant 2010 USD) in 2036.

JEL Classification: Q43; Q54; Q57

\section{INTRODUCTION}

There is a high degree of scientific consensus regarding to the level of global warming that is causing climate changes. Global mean temperature rise, due to $\mathrm{CO} 2$ and other greenhouse gases $(\mathrm{GHG})$ concentration levels in the atmosphere, should not exceed $2^{\circ} \mathrm{C}$ from pre-industrial times. The agreement on this value was reached at the Conference of the Parties (COP) 16, held in Cancún in 2010 [1]. This political target was established based on several studies [2,3], which had calculated the first estimation of the emission reductions needed. That threshold has been subject to some criticism and revision, even by the very same authors that helped to define it. To keep the temperature below $2{ }^{\circ} \mathrm{C}[1-4]$, the emission reduction in 2020 was estimated to be around 25-40\% comparing to 1990 baseline levels, and $50-80 \%$ for 2050. One of the reasons for this skepticism is the high level of uncertainty involved to reduce emissions [5]. Scientists also estimate the critical threshold for $\mathrm{CO} 2$ concentration levels in the atmosphere to be within 450 and $500 \mathrm{ppm}$ of $\mathrm{CO} 2$ based on the $2{ }^{\circ} \mathrm{C}$ rise [2] (parts per million (ppm) is the ratio between the number of molecules in a gas and the number of molecules in dry air [6] ). Above this level, impacts on global climate regulation would be irreversible. These approaches have also been contested by some authors [7] who doubt the usefulness of the concept of climate stability. Only a holistic approach (economic, social and environmental) in the international context can avoid the major ecological disaster humanity has been facing in the last centuries, originated by global warming and climate change.

The level of $\mathrm{CO} 2$ emissions, and therefore the concentration in the atmosphere, depends on energy consumption, mostly composed of fossil fuels. Since energy consumption is strongly linked to economic growth and Gross Domestic Product (GDP), as shown by several studies [8-11], the existence of a critical threshold for greenhouse gases in the atmosphere could imply the existence of a critical level for fossil fuels and therefore, 
for income. Above that level, we would interfere with climate regulation. One could argue that the link between energy consumption and GDP alone is not enough, as the world could change its energy mix towards low-carbon options. In fact, there is an ongoing debate about this issue. On the one hand, there are economies decarbonizing prior to 1990, although at only $0.3 \%$ per year [12]. This is the case for China and some other economies. A structural decomposition analysis for China found that the country had reduced carbon intensity especially due to structural changes in the economy and through the substitution of energy sources [13]. However, total emissions kept growing in the analyzed period. The same approach was used for the Baltic countries, finding improvements only in carbon intensity but not in total carbon emissions [14]. This optimism is shared by other authors who assert that well-being could be decoupled from energy consumption and carbon emissions [15].

On the other hand, some authors [16] show how carbon emissions have been rising by more than 2\% per year since 1990, and the carbon intensity reductions, agreed in the Copenhagen pledges, would easily be surpassed by GDP growth rates. South Korea is a great example of a fast-growing country increasing its carbon intensity [17]. Some other authors [18] are skeptical about decarbonization approaches and question some of the assumptions made in mitigation models, which tend to discontinue the relation between energy consumption and GDP, i.e., leapfrogging. The authors, however, point out that historical and current trends do not support those assumptions, making leapfrogging less likely. Decarbonization is needed, but it will be costly [19] and it should go along demand-side measures such as establishing caps for energy consumption [20]. However, despite the literature discussed above and the ongoing discussions in policy and academic forums, nowadays the world is not experiencing a process of decarbonization, as shown in Figure 1. 


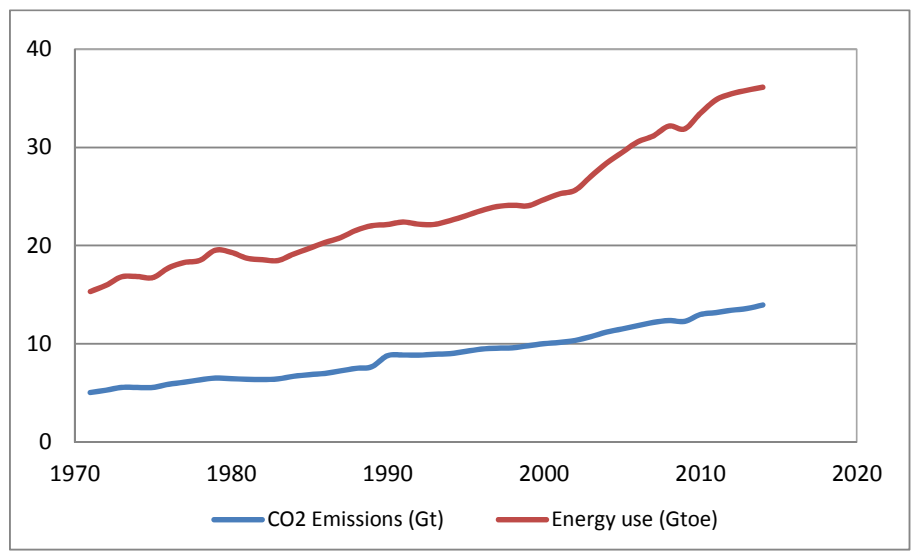

Figure 1. Global carbon emissions and primary energy, 1971-2013. Source: [21].

In the 44 years period from 1971 to 2014 , the link between energy use and carbon emissions has remained close. In the period 1971-1980, world energy consumption increased, on average, at $2.4 \%$ per year, while $\mathrm{CO}_{2}$ emissions increased at a yearly rate of $2 \%$. Despite of the advances in energy efficiency and in the share of renewable sources, $\mathrm{CO}_{2}$ emissions have increased in relative terms with respect to energy consumption. This result is in line with the work of some authors [22] who found that a scenario of no climate change or no technology transfer fits better with historical trends for India, the USA and Europe. Therefore, by considering the link between energy and carbon emissions, as well as between energy consumption and GDP as stated above, this research did not enter the discussion of decarbonization directly, but included it in two ways: (i) by considering the improvements in energy efficiency that can come with the transfer of technology; and (ii) by accounting for recent voluntary commitments, the so-called Intended Nationally Determined Contributions (INDC), presented in the Paris Agreement in the COP21 that took place in Paris in December 2015.

This research relied also on the approach of contraction and convergence (C\&C), introduced in 1996 by Aubrey Meyer at the Global Commons Institute in the UK [23-25]. The main idea of the approach is that we could consider the atmosphere as global commons to which every individual would have the same right of access. That would imply having 
the same right to emit greenhouse gases. Under this approach, global emissions should be distributed among countries in a per capita egalitarian way, taking as a reference one base year, for instance 2014. The goal would be that emissions per capita would be equal for all countries in a target year, for example 2050. This would imply that countries with emission levels above their target would need to reduce their levels, so that every country would converge to the equal per capita level defined for the final year.

Due to the relation between $\mathrm{CO}_{2}$ emissions, GDP, energy consumption and energy efficiency, a certain level of income could be understood as toxic when it is accompanied by a level of $\mathrm{CO}_{2}$ emissions incompatible with keeping climate change under certain control.

This new concept is regarded as useful for understanding human-nature relations. Moreover, it helps in understanding income inequalityamong nations. To test the concept, a simulation model was designed that estimates, under certain assumptions or parameters, the year in which toxic income would be reached. This exercise is not exempt from limitations, the main one being that the level of uncertainty increases as the period simulated increases. However, this limitation is only relative in the sense that the interest does not lie on the particular value for toxic income but on its dynamics over time.

\section{Toxic Income}

Conventional economic theory asserts that one of the main goals of economic policy is to increase the income level [26]. For instance, the axiom of non-satiation preferences assumes that more is better; but this is not necessarily true, as higher consumption levels imply higher environmental impacts, as in the case with $\mathrm{CO}_{2}$ emissions. Under this consideration, one could ask if a particular level of income could be considered "toxic" in the sense that it could induce to $\mathrm{CO}_{2}$ emissions incompatible with climate regulation.

According to accounting rules, oil companies usually record among their assets oil and coal reserves valued at market prices. This helps companies to increase their total assets: the more reserves a company has, the wealthier that company is. However, what would happen if all those reserves were extracted and burnt?

One of the clearest and most updated answers to that question is found in [27]. According to the authors, maintaining temperature rise below $2{ }^{\circ} \mathrm{C}$ implies that we have to keep in the ground one third of current oil reserves, half of natural gas reserves, and $82 \%$ of coal reserves until year 2050. The implication of this is that hydrocarbon companies are accounting in their books some toxic assets, and therefore their balances can be questioned [28]. 
When speaking of income, we are referring to a distribution of per capita income, since not all countries have the same levels of per capita income, and even within each country disparities on income arise. Future income distribution depends on the different growth trajectories of each country. In a simplified way, the fastest-growing countries are the upper-middle income countries, followed by the low-middle income countries, with high-income and low-income countries lagging behind. These different rates of growth are modifying the distribution of (toxic) income.

Generally speaking, increases in economic income might be harmful for the environment, but there are actions of effective decarbonization and distributive improvements. Other factors that affect the determination of toxic income are energy efficiency (GDP/energy consumption) and carbon intensity $\left(\mathrm{CO}_{2}\right.$ emissions/GDP). Both variables are closely related to the degree of technological development of a country and the economic structure of a country, as shown, for instance, by York et al. [29]. In a very simple way, with more technology we can find less energy consumption and less $\mathrm{CO}_{2}$ emissions in relative terms. Similarly, in a very simplified way, we can say that industrial economies have higher levels of emission of pollutants than agrarian or services economies. Of course, we have to consider the levels of affluence or intensity of consumption. The Jevons' paradox also works here, i.e., efficiency improvements can lead to a reduction in prices and, therefore, to an increase in consumption that ends up with higher total levels of consumption (and emission of pollutants) per capita [30].

Finally, the uncertainty mentioned above about the critical thresholds of $\mathrm{CO}_{2}$ concentration of greenhouse gases $(\mathrm{GHG})\left(\mathrm{CO}_{2}, \mathrm{CH}_{4}, \mathrm{~N}_{2} \mathrm{O}, \mathrm{HFCs}\right.$, PFCs and $\mathrm{SF}_{6}$ ) induces a high degree of uncertainty in the distribution of toxic revenue.

Thus, the toxic income would be the per capita income distribution that would generate levels of GHG emissions incompatible with the maintenance of climate change under control. Thus, toxic income depends on the atmospheric concentration of GHG, which depends on population, consumption levels, economic growth trajectories of different countries, energy efficiency, carbon intensity and physical conditions. The toxic income is also a dynamic concept as it depends on the changes in these different variables over time. 


\section{DATA}

Data sources used to estimate toxic income are the following: "World Development Indicators" (WDI) database of the World Bank [21]; "World Population Prospects" of the United Nations, Department of Economic and Social Affairs, Population Division [31]; and the European Environment Agency (EEA) [32]. We selected the following series: population [21,31], total and per capita energy consumption, total and per capita $\mathrm{CO}_{2}$ and $\mathrm{GHG}$ emissions, total energy consumption, total and per capita real GDP (base year 2010) [21] and atmospheric greenhouse gas (GHG) concentrations (EEA) [32]. World Bank's income groups were used for grouping countries: low income, middle income (lower and upper) and high income.

Tables 1-5 describe the global framework for the variables mentioned above: population, GDP, $\mathrm{CO}_{2}$ emissions and energy consumption, grouped by income levels.

Table 1. Population.

\begin{tabular}{ccccc}
\hline & & \multicolumn{3}{c}{ Population } \\
\cline { 3 - 4 } Income Group & Number of Countries & \multicolumn{2}{c}{2014} & $\begin{array}{c}\text { Annual Growth } \\
\text { Rate 1992-2014 (\%) }\end{array}$ \\
\cline { 3 - 5 } & & (Millions) & \% Share & 0.7 \\
High income & 78 & 1176 & 16.2 & 0.9 \\
Upper middle income & 56 & 2541 & 35.0 & 1.7 \\
Lower middle income & 52 & 2927 & 40.3 & 2.8 \\
Low income & 31 & 625 & 8.6 & 1.3 \\
World & 217 & 7269 & 100.0 & \\
\hline
\end{tabular}

Source: [21]. 
Table 2. GDP.

\begin{tabular}{|c|c|c|c|c|c|}
\hline \multirow{3}{*}{ Income Group } & \multicolumn{3}{|c|}{ GDP } & \multicolumn{2}{|c|}{ Per Capita GDP } \\
\hline & \multicolumn{2}{|c|}{2014} & \multirow{2}{*}{$\begin{array}{l}\text { Annual } \\
\text { Growth Rate } \\
\text { 1992-2014 (\%) }\end{array}$} & \multirow{2}{*}{$\begin{array}{c}2014 \\
\text { (US\$2010) }\end{array}$} & \multirow{2}{*}{$\begin{array}{c}\text { Annual } \\
\text { Growth Rate } \\
\text { 1992-2014 (\%) }\end{array}$} \\
\hline & $\begin{array}{l}\text { (Trillion } \\
\text { US\$2010) }\end{array}$ & $\%$ Share & & & \\
\hline High income & 48.2 & 65.5 & 2.1 & 40,983 & 1.4 \\
\hline Upper middle income & 19.3 & 26.2 & 4.8 & 7577 & 3.9 \\
\hline Lower middle income & 5.8 & 7.8 & 5.0 & 1968 & 3.2 \\
\hline Low income & 0.36 & 0.5 & 3.9 & 578 & 1.1 \\
\hline World & 73.6 & 100.0 & 2.9 & 10,119 & 1.5 \\
\hline
\end{tabular}

Table 3. $\mathrm{CO}_{2}$ Emissions.

\begin{tabular}{|c|c|c|c|c|c|}
\hline \multirow{3}{*}{ Income Group } & \multicolumn{3}{|c|}{$\mathrm{CO}_{2}$ Emissions } & \multirow{3}{*}{$\begin{array}{c}\text { Per capita CO } \\
2014 \\
(\mathrm{t})\end{array}$} & \multirow{3}{*}{$\begin{array}{c}{ }_{2} \text { Emissions } \\
\text { Annual } \\
\text { Growth Rate } \\
1992-2014(\%)\end{array}$} \\
\hline & \multicolumn{2}{|c|}{2014} & \multirow{2}{*}{$\begin{array}{c}\text { Annual } \\
\text { Growth Rate } \\
\text { 1992-2014 (\%) }\end{array}$} & & \\
\hline & $(\mathrm{Gt})$ & $\%$ Share & & & \\
\hline High income & 12.9 & 35.7 & 0.4 & 11.0 & -0.2 \\
\hline Upper middle income & 16.8 & 46.4 & 3.7 & 6.6 & 2.8 \\
\hline Lower middle income & 4.3 & 11.9 & 3.1 & 1.5 & 1.4 \\
\hline Low income & 0.2 & 0.4 & $2.4 *$ & 0.3 & $-0.3 *$ \\
\hline World & 36.1 & 100 & 2.2 & 5.0 & 0.9 \\
\hline
\end{tabular}

Source: [21]. * 1998-2014.

Table 4. Energy consumption.

\begin{tabular}{|c|c|c|c|c|c|}
\hline \multirow{3}{*}{ Income Group } & \multicolumn{3}{|c|}{ Energy Use } & \multicolumn{2}{|c|}{ Per Capita Energy Use } \\
\hline & \multicolumn{2}{|c|}{2014} & \multirow{2}{*}{$\begin{array}{c}\text { Annual } \\
\text { Growth Rate } \\
\text { 1992-2014 (\%) }\end{array}$} & \multirow{2}{*}{$\begin{array}{l}2014 \\
\text { (Toe) }\end{array}$} & \multirow{2}{*}{$\begin{array}{c}\text { Annual } \\
\text { Growth Rate } \\
\text { 1992-2014 (\%) }\end{array}$} \\
\hline & (G toe) * & $\%$ Share & & & \\
\hline High income & 5.6 & 42.2 & 0.8 & 4.8 & 0.1 \\
\hline Upper middle income & 5.6 & 42.4 & 3.3 & 2.2 & 2.4 \\
\hline Lower middle income & 1.9 & 14.3 & 2.6 & 0.6 & 0.9 \\
\hline Low income & 0.2 & 1.2 & $2.9 * *$ & 0.4 & $0.3 *$ \\
\hline World & 14.0 & 100 & 2.1 & 1.9 & 0.8 \\
\hline
\end{tabular}

Table 5. Energy e fficiency (PIB /Energy).

\begin{tabular}{ccc}
\hline \multirow{2}{*}{ Income Group } & \multicolumn{2}{c}{ Energy E fficiency } \\
\cline { 2 - 3 } & $\begin{array}{c}2014 \\
(\$ / K o e)\end{array}$ & $\begin{array}{c}\text { *nnual Growth Rate } \\
1992-2014(\%)\end{array}$ \\
\hline High income & 8.62 & 1.3 \\
\hline Upper middle income & 3.42 & 1.6 \\
\hline Lower middle income & 3.04 & 2.5 \\
\hline Low income & 1.28 & $1.4{ }^{* *}$ \\
\hline World & 5.27 & 0.9 \\
\hline Source: [21]. * koe: Kilograms of oil equivalent. ${ }^{* *} 1996-2014$.
\end{tabular}


Data in Tables 1-5 present a reality in the world with high levels of inequality in income levels, $\mathrm{CO}_{2}$ emissions, energy consumption, and energy efficiency, with gaps between countries that seem difficult to reduce. For instance, the high-income group of countries represents $16.2 \%$ of world population, while is responsible for $65.5 \%$ of world GDP, $35.7 \%$ of $\mathrm{CO}_{2}$ emissions, and $42.2 \%$ of energy consumption, and they have an average energy efficiency of $8.62 \$ / k o e$. On the other hand, countries of the lower middle income category represent $40.3 \%$ of world population, but they only generate $7.8 \%$ of world GDP, $11.9 \%$ of $\mathrm{CO}_{2}$ emissions, and $14.3 \%$ of world energy consumption, and they do have a much lower energy efficiency at only $3.04 \$ /$ koe. In other words, an average citizen of a high income country has an average GDP 20.9 times higher, emits 7.3 times more $\mathrm{CO}_{2}$, and has an energy consumption eight times higher than an average citizen of a lower middle income country. Moreover, energy efficiency is also 2.8 times higher in high income countries.

\section{Methodology}

Even though projections for $\mathrm{CO}_{2}$ emissions considering a number of future scenarios by the Intergovernmental Panel on Climate Change (IPCC) exist, to estimate toxic income, we need projections that establish a parametric relation between $\mathrm{CO}_{2}$ emissions, GHGs and income (measured by GDP). This is why econometric models were used to establish the relation between the variables. In a country-base way, the following econometric models were applied:

\footnotetext{
Linear model: $\mathrm{CO}_{t}=\beta_{0}+\beta_{1} y_{t}+\beta_{2} E_{t}+\varepsilon_{t}$

Linear spline model: $C O 2_{t}=\beta_{0}+\beta_{1} y_{t \mid y 0}+\beta_{2} y_{t \mid y 0}^{*}+\beta_{3} E_{t}+\varepsilon_{t}$

Quadratic spline model: $C O 2_{t}=\beta_{0}+\beta_{1} y_{t y 0}+\beta_{2} y^{2}{ }_{t y 0}+\beta 3 y^{*}{ }_{t y 0}+\beta_{4} E_{t}+\varepsilon_{t}$
}

Where

$t$ is the time index;

$\mathrm{CO}_{2 \mathrm{t}}$ is per capita $\mathrm{CO}_{2}$ emissions;

$y_{t}$ is per capita GDP in year $t$;

$y_{0}$ is the income threshold between the two sections of the regression;

$E_{t}$ is energy efficiency defined as: GDP/energy consumption; and

$\varepsilon_{t}$ is the stochastic error with mean value of zero and constant variance. 


$$
\begin{array}{r}
y_{t \mid y 0}=\min \left(y_{t}, y_{0}\right)=\left\{\begin{array}{l}
y_{t} \text { if } y_{t} \leq y_{0} \\
y_{0} \text { if } y_{t}>y_{0}
\end{array}\right. \\
y_{t \mid y 0}^{*}=\max \left(y_{t}-y_{0}, 0\right)=\left\{\begin{array}{c}
0 \text { if } y_{t} \leq y_{0} \\
y_{t}-y_{0} \text { if } y_{t}>y_{0}
\end{array}\right.
\end{array}
$$

Without accounting for energy efficiency, these models allow expressing several functional forms for the relation GDPpc- $\mathrm{CO}_{2}$ pcemissions: positive or negative linear function (or spline), environmental Kuznets curve (EKC) (inverse- $U$ or inverse-V), and weak environmental Kuznets curve ( $\Gamma$-curve or $\mathrm{N}$-curve, that is, inverse- $U$ or inverse- $V$ shape, followed by a constant, positive or negative trench). These functional forms allow adjusting data in a very acceptable manner as well as creating long-term projections (20-30 years) for the dependent variable $\left(\mathrm{CO}_{2} \mathrm{pc}\right)$.

The traditional EKC presents an inverted U-shaped empiric relation between income and pollution. In theory, higher income causes at first an increase in environmental impact, while this is reduced when income reaches a certain value. The peak of the inverted $U$ is the inflection point of pollution. In the weak version of the EKC, once the inflection point is reached, pollution does not decrease but remains stable for a good review of the EKC, see [33].

To get an econometric model for a specific country, the following procedure was used.
1. First, we verified that emissions per capita and income per capita were co-integrated. For all countries, both time series were integrated of order $1, I(1)$, with the exception of China, whose time series were integrated of order $2, I(2)$. Then, the parameters were estimated using ordinary least squares (OLS). All econometric equations generated stationary residual at $5 \%$ level except for China and the Democratic Republic of Congo, whose residual were stationary at 10\% level of significance. Therefore, the estimated parameters by OLS continued having good properties. In fact, the estimators were super consistent; they converged to the true value at a rate $1 / \pi$, instead of the habitual convergence ratio $1 / \sqrt{ } \mathrm{T}$ [34].

2. For low income countries, we applied only the linear model; for lower-middle income countries, we selected between the linear and the linear spline model. In both cases, the assumption is made of a positive relation between $\mathrm{CO}_{2}$ emissions and income. For upper middle and high income countries, we selected among the three models. The final section of the econometric function may have a positive, negative, or null slope, for those countries. The selection of the final model to be used was linked to the lowest value for the Akaike Informa- 
tion Criterion (AIC).

3. In the case of spline regression models, for each value of income, $y_{t}$, a regression was estimated, and then the income threshold $y_{0}$ was computed minimizing the Akaike information criterion, that is, $y_{0}=\min _{y t} A I C$.

4. Additionally, errors autocorrelation was verified. In the presence of autocorrelation, thecorrection term AR (1) was applied.

5. Finally, we only included countries with a coefficient of determination $R^{2}$ larger than 0.6.

We ended up with 76 countries, which make up $76.7 \%$ of world's population and $76.9 \%$ of world's $\mathrm{CO}_{2}$ emissions. A summary of the number of countries per income level and the resulting econometric regressions is presented in Table 6 .

Table 6. Econometric models.

\begin{tabular}{|c|c|c|c|c|c|c|c|}
\hline \multirow{2}{*}{ Income Group } & \multicolumn{3}{|c|}{ Econometric Model } & \multirow{2}{*}{$\begin{array}{c}\text { Number of } \\
\text { Countries }\end{array}$} & \multicolumn{3}{|c|}{ Percentage of World's } \\
\hline & Linear & Linear Spline & Quadratic Spline & & Population (\%) & $\mathrm{CO}$ & 2 Emissions (\%) \\
\hline $\mathrm{High}$ income & & 8 & 23 & 31 & 12.8 & & 28.6 \\
\hline Upper middle income & 3 & 4 & 18 & 25 & 30.6 & & 38.9 \\
\hline Lower middle income & 3 & 12 & & 15 & 29.9 & & 9.3 \\
\hline Low income & 5 & & & 5 & 3.4 & & 0.1 \\
\hline Total & 11 & 24 & 41 & 76 & 76.7 & & 76.9 \\
\hline
\end{tabular}

Low income countries have a real problem of data availability. Only 10 out of 31 countries included in this group have complete time series for energy consumption in the period 1971-2014. Data on variables such population, GP and $\mathrm{CO}_{2}$ emissions are complete. The outcome was that half of these countries show deficient econometric adjustments. This is also due to their lack of a strong industrial sector, which implies the link between GDP per capita and $\mathrm{CO}_{2}$ emissions per capita is not clear. There may also be problems with the reliability of data. However, the use of 5 out of 31 countries belonging to this group does not generate an important bias to our results. This is explained as follows: (1) the group of low income countries represents a small share in global $\mathrm{CO}_{2}$ emissions (0.4\%, see Table 3$)$ and global income $(0.5 \%$, see Table 2$)$; and (2) the econometric results are extended to the income group by means of expansion factors. In 2014, these five countries represented $25.4 \%$ of population, $38.2 \%$ of $\mathrm{CO}_{2}$ emissions and $17.7 \%$ of income of their group, therefore the possibility of a bias is reduced.

As an example, the results of the parameters estimated for the USA, China, India and Ethiopia are shown in Table 7. 
Figure $2 \mathrm{a}-\mathrm{d}$ shows the regression graphs. Appendix A.

The complete estimates are provided in

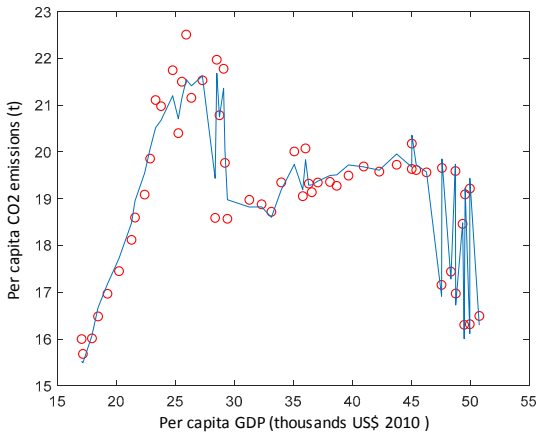

(a) United States

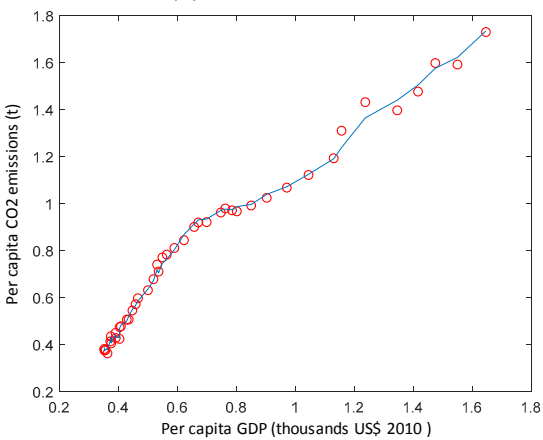

(c) India

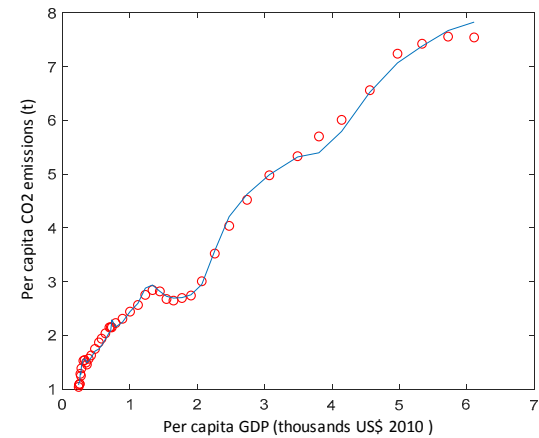

(b) China

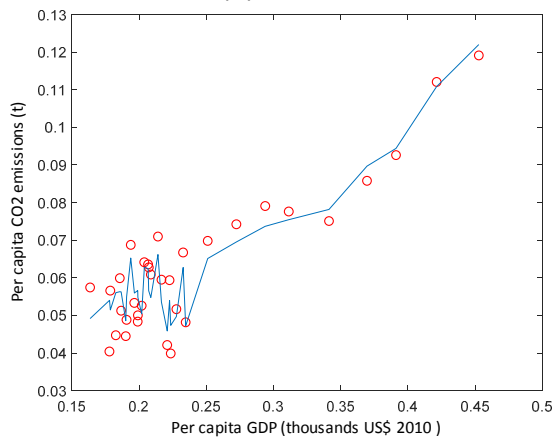

(d) Ethiopia

Figure 2. Per capita GDP-Per capita $\mathrm{CO}_{2}$ emissions regressions. 
Table 7. Results of the estimated parameters.

\begin{tabular}{cccccc}
\hline \multicolumn{3}{c}{ United States } & \multicolumn{3}{l}{ China } \\
\hline Model: & Quadratic Spline & Model: & Quadratic Spline ${ }^{*}$ \\
\hline$R^{2}$ & 0.97 & & $R^{2}$ & 0.94 & \\
\hline$\beta_{0}$ & 1.00 & $(0.47)$ & $\beta_{0}$ & 1.30 & $(3.2)$ \\
\hline$y_{t \mid y_{0}}$ & 2.14 & $(13.4)$ & $y_{t \mid y_{0}}$ & 5.60 & $(6.5)$ \\
\hline$y_{t \mid y_{0}}^{2}$ & -0.03 & $(-9.8)$ & $y_{t \mid y_{0}}^{2}$ & -0.91 & $(-3.5)$ \\
\hline$y_{t \mid y_{0}}^{*}$ & 0.53 & $(18.1)$ & $y_{t \mid y_{0}}^{*}$ & 1.57 & $(16.3)$ \\
\hline$E_{t}$ & -4.16 & $(-21.6)$ & $E_{t}$ & -2.81 & $(-10.0)$ \\
\hline$y_{0}$ & 31.27 & & $A R(1)$ & 0.79 & $(4.1)$ \\
\hline$d$ & 1.80 & & $y_{0}$ & 2.26 & \\
\hline AIC & 0.63 & & $d$ & 1.46 & \\
\hline ndat & 55 & & AIC & -1.06 & \\
\hline & & & ndat & 44 & \\
\hline
\end{tabular}

(b)

\begin{tabular}{cccccc}
\hline \multicolumn{3}{l}{ India } & \multicolumn{3}{c}{ Ethiopia } \\
\hline Model: & \multicolumn{2}{l}{ Linear Spline ${ }^{*}$} & Model: & \multicolumn{2}{c}{ Linear } \\
\hline$R^{2}$ & 0.99 & & $R^{2}$ & 0.91 & \\
\hline$\beta_{0}$ & 0.27 & $(3.5)$ & $\beta_{0}$ & 0.067 & $(7.4)$ \\
\hline$y_{t \mid y_{0}}$ & 2.48 & $(17.2)$ & $y_{t}$ & 4.248 & $(7.2)$ \\
\hline$y_{t \mid y_{0}}^{*}$ & 1.36 & $(17.1)$ & $E_{t}$ & -2.05 & $(-6.8)$ \\
\hline$E_{t}$ & -0.58 & $(-7.5)$ & $d$ & 2.211 & \\
\hline$A R(1)$ & 0.24 & $(2.4)$ & AIC & -7.434 \\
\hline$y_{0}$ & 0.66 & \multicolumn{5}{c}{34} \\
\hline$d$ & 1.83 & ndat & \\
\hline AIC & -4.77 & & & \\
\hline ndat & 44 & & &
\end{tabular}


The estimate for toxic income was carried out through a simulation model that estimates the values of the variables for the period 2014-2040. GDP per capita and energy efficiency were projected using the values in the base year and applying growth rates. Those rates were established according to the simulation scenario. On the other hand, population projections were taken from United Nations Population Division.

The estimation of $\mathrm{CO}_{2}$ emissions, greenhouse gases $(\mathrm{GHG})$ and toxic income is described schematically in Figure 3 .

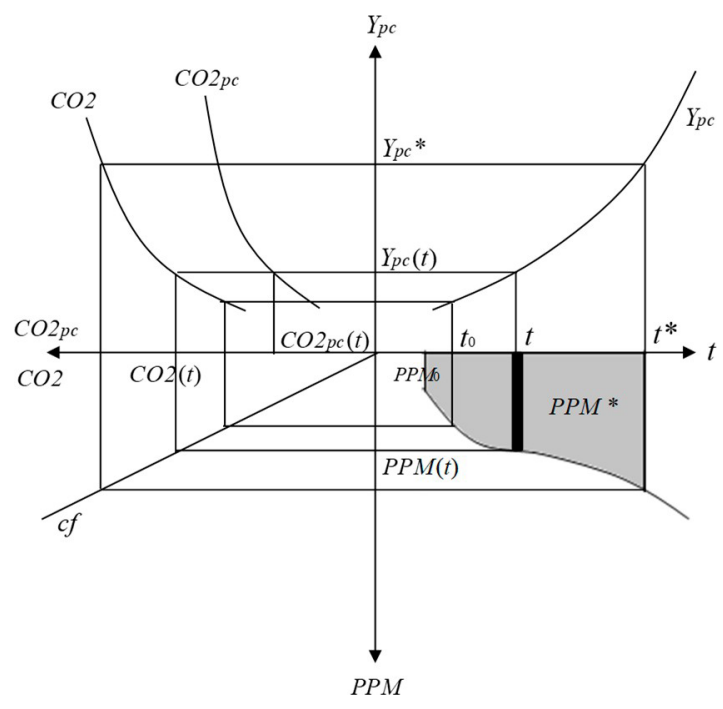

Figure 3. Toxic income estimation.

The positive side of the $x$-axis shows time; the negative one shows total and per capita $\mathrm{CO}_{2}$ emissions. The positive side of the $y$-axis plots GDP per capita and the negative, total $\mathrm{CO}_{2}$ emissions expressed in ppm.

As time goes from t0 onwards, income per capita increases, determin- ing the per capita income Ypc locus. The econometric equation, represented graphically by the curve $\mathrm{CO}_{2} \mathrm{pc}$, establishes its value depending on the per capita income and energy efficiency (this latter variable is not shown in Figure 3). Multiplying this value by population, total $\mathrm{CO}_{2}$ is obtained $\left(\mathrm{CO}_{2}\right.$ locus). 
A percentage of the stream emissions are captured by the biosphere (soil, oceans and vegetation) and other, the residual, remains in the atmosphere (it is transformed into a stock). This lasting $\mathrm{CO}_{2}$ flow is expressed in ppm units by applying the corresponding conversion factor (cf locus). PPM(t) is the flow of $\mathrm{CO}_{2}$ retained in the atmosphere and accumulated year by year to the initial stock (PPM0) - the shaded area in the fourth quadrant of Figure 3. When the accumulated $\mathrm{CO}_{2}$ emissions reach the critical threshold determined as PPM*, that is when the shaded area is equal to PPM*, the critical period $t^{*}$ is reached. Then, the critical time $t^{*}$ is defined by:

$$
P P M 0+\int_{t_{0}}^{t^{*}} P P M(t) d t=P P M^{*}(1)
$$

where $P P M_{0}$ is the atmospheric concentration of $\mathrm{CO}_{2}$ in the base year for the simulation (year 2014). The toxic income is then defined as $Y_{p c}^{*}$ where:

$$
Y_{p c}^{*}=Y_{p c}\left(t^{*}\right)
$$

Income per capita in each year $t$, $Y p c(t)$, is a vector containing the GDP per capita values of the $m=76$ countries included in the simulation model, thus the toxic income $Y^{*} p c$ is really a set with $m$ elements $\left(Y_{p c}^{*}=\left\{Y_{p c}\left(t^{*}\right)_{i}, i=1,2, \ldots, m\right\}\right)$.
A more refined definition of toxic income is to define it as the probability density of the income distribution over the critical period $t^{*}$. These 76 countries can be viewed as a sample of all countries in the world. To account for global emissions, we used the corresponding expansion factors for each income group, which were simply calculated by the quotient between total $\mathrm{CO}_{2}$ emissions and $\mathrm{CO}_{2}$ emission added up for the countries in the simulation model.

For simplicity, the model in Figure 3 only shows the flow for a single country. On the other hand, the graph presents the factors that affect the result for the toxic income: (1) the world's income distribution (levels of per capita GDP for the countries); (2) the diverse paths of economic growth; (3) the relation between real per capita income and per capita $\mathrm{CO}_{2}$ emissions (which depend on economic structure, energy sources, technology and consumption levels); (4) population and population growth; and (5) $\mathrm{CO}_{2}$ sinks ("bad" sinks: oceans and soil; and "good" ones: forests). Thus, the estimates for the toxic income $Y_{p c}^{*}$ and for the critical time $t^{*}$ change with the parameters and assumptions of the simulation.

Equations (1) and (2) can also be used to define the toxic input from the $\mathrm{GHG}$ concentration instead of $\mathrm{CO}_{2}$ concentration. We assumed that there 
is a stable relation between global $\mathrm{CO}_{2}$ emissions and global GHG emissions. For 2008-2012, the ratio of global $\mathrm{CO}_{2}$ and GHG emissions was 0.6608. Following (IPCC, 2014), we assumed that $40 \%$ of $\mathrm{CO}_{2}$ emissions remain in the atmosphere. For greenhouse gases (GHG), this percentage is $42 \%$ (this parameter was estimated from the equation: $G H G_{t}(p p m)=$ $\mathrm{GHG}_{t-1}(\mathrm{ppm})+a \times G H G(t) / 7.8$, thus the values of $G H G_{t}$ are equal for the extreme years of the period 1990-2013). On the other hand, the technical coefficient to transform the flow of $\mathrm{CO}_{2}$ emissions in ppm is 7.8 (7.8 Gigatons of $\mathrm{CO}_{2} \approx 1$ ppm) [35].

As indicated in the Introduction, there is a great deal of uncertainty about the critical level of concentrations that can lead to an increase in global average temperature and the effects that could be caused by climate change. To simplify this analysis, we took as critical threshold a concentration of 530 ppm of GHG. Mitigation scenarios reaching concentration levels of about 530 ppm of GHG are more likely than not to limit temperature change to less than $2^{\circ} \mathrm{C}[36]$.

\section{Simulation scenarios}

As is common in simulation studies, we considered two scenarios. The business as usual scenario considered that the future replicates the past, and the intervention scenario reflected the political will to change current trends for a desired future. In this second scenario, an attempt was made to reflect the results of the commitments of the COP21 meeting held in Paris in December 2015. By 15 October 2015, 147 countries presented 119 Intended Nationally Determined Contributions (INDC).

To calculate the critical time and the toxic income, data for 26 years were projected, from the base year 2014 to 2040. In both scenarios, estimated population corresponded to projections from the UN Population Division [31].

Additionally, since the USA, China and India combined represent 52\% of global emissions and the USA alone accounts for $40.7 \%$ of emissions in its income group, China accounts for $61.4 \%$ of emissions of its group and India accounts for $52 \%$ of emissions of its group, each of these countries was analyzed as if it were a group itself.

\section{Business as usual scenario}

For the Business as Usual (BaU) scenario, in the case of per capita GDP and energy efficiency (EE) growth, we used the average growth rate for the period 1992-2014. In the period 2014-2016, we used actual per capita GDP data. As USA, China and India share the greatest percentage $(52 \%)$ of global $\mathrm{CO}_{2}$ emissions, we used their own growth rates; except for China's per capita GDP growth, 
which was assumed to be equal to India's growth as the economic growth of China has lowered in the last years. From 2031 onwards, we assumed these countries behave the same as their income group (see Table 8).

Table 8. Business as usual (BaU) scenario.

\begin{tabular}{|c|c|c|c|c|c|}
\hline & \multicolumn{3}{|c|}{ GDP Growth (\%) } & \multicolumn{2}{|c|}{ EE Growth (\%) } \\
\hline & 2014-2016 & $2017-2030$ & $2031-2040$ & $2013-2030$ & $2031-2040$ \\
\hline High income-USA & \multirow{7}{*}{ Actual data } & \multicolumn{2}{|c|}{1.3} & \multicolumn{2}{|c|}{1.0} \\
\hline Upper middle-China & & \multicolumn{2}{|c|}{1.8} & \multicolumn{2}{|c|}{1.6} \\
\hline Lower middle_India & & \multicolumn{2}{|c|}{2.4} & \multicolumn{2}{|c|}{2.8} \\
\hline Low income & & \multicolumn{2}{|c|}{1.1} & \multicolumn{2}{|c|}{1.4} \\
\hline USA & & 1.5 & 1.3 & 1.9 & 1.0 \\
\hline China & & 5.1 & 1.8 & 4.2 & 1.6 \\
\hline India & & 5.1 & 2.4 & 2.5 & 2.8 \\
\hline
\end{tabular}

COP21 scenario.

When the estimates for per capita $\mathrm{CO}_{2}$ emissions trajectory decreased, according to the C\&C approach, we supposed the trajectory converged to the 2012 world's mean, 5 tons per capita.

In the so-called COP21 scenario, we assumed that $\mathrm{CO}_{2}$ emissions follow a consistent path with the proposals presented by nations at the COP21. Following the synthesis report for these INDC [37], aggregate greenhouse gas emissions are expected to grow, when compared to 2010 levels, by $13 \%$ in year 2025 and $17 \%$ in 2030.

In this second scenario, we assumed that the abatement of $\mathrm{CO}_{2}$ emissions was fulfilled by lessening the income growth rate and increasing energy efficiency. From 2018 to 2030, we established an ad-hoc growth rate for per capita GDP and adjust the energy efficiency growth rate to satisfy the restrictions on COP21 scenario. Specifically, we assumed that economic growth in rich countries (medium and medium-high income) is halved, India reduces its growth 1\% and China grows at the same rate as India. Taking into consideration that, for lower-medium and low income level countries, the lack of growth is problematic, poor countries do not reduce their economic growth rate. From year 2031 onwards, we assumed that the changes in economic growth and energy efficiency return to their historical values (see Table $9 a, b)$. 
Table 9. (a) COP 21 scenario. GDP growth. (b) COP 21 scenario. Energy efficiency growth.

\begin{tabular}{|c|c|c|c|c|}
\hline \multicolumn{5}{|c|}{ (a) } \\
\hline & \multicolumn{4}{|c|}{ GDP Growth (g) } \\
\hline & 2014-2016 & 2017-2030 (\%) & $2031-$ & (\%) \\
\hline High income-USA & \multirow{7}{*}{$\begin{array}{c}\text { Actual } \\
\text { Data }\end{array}$} & 0.7 & \multicolumn{2}{|c|}{1.3} \\
\hline Upper middle-China & & 0.9 & \multicolumn{2}{|c|}{1.8} \\
\hline Lower middle-India & & 2.4 & \multicolumn{2}{|c|}{2.4} \\
\hline Low income & & 1.1 & \multicolumn{2}{|c|}{1.1} \\
\hline USA & & 0.8 & \multicolumn{2}{|c|}{1.3} \\
\hline China & & 4.1 & \multicolumn{2}{|c|}{1.8} \\
\hline India & & 4.1 & \multicolumn{2}{|c|}{2.4} \\
\hline \multicolumn{5}{|c|}{ (b) } \\
\hline & \multicolumn{4}{|c|}{ EE Growth (\%) } \\
\hline & 2014-2017 & 2018-2025 & $2025-2030$ & 2030-2040 \\
\hline High income-USA & 1.0 & 2.4 & 2.5 & 1.0 \\
\hline Upper middle-China & 1.6 & 3.1 & 3.1 & 1.6 \\
\hline Lower middle-India & 2.8 & 4.2 & 4.3 & 2.8 \\
\hline Low income & 1.4 & 2.9 & 3.0 & 1.4 \\
\hline USA & 1.9 & 3.4 & 3.5 & 1.9 \\
\hline China & 4.2 & 5.7 & 5.8 & 4.2 \\
\hline India & 2.5 & 3.9 & 4.0 & 2.5 \\
\hline
\end{tabular}

\section{RESULTS AND DISCUSSION}

The critical period $t^{*}$ is reached when GHG concentration in the atmosphere reaches the threshold of $530 \mathrm{ppm}$ (Figure 4). Under the assumptions of the BaU scenario, the critical time is $t^{*}=2033$ that is, in 14 years from the current year 2019. For the scenario COP21, the critical period is extended only by three years, until $t^{*}=2036$. The main explanation for this limited difference between the scenarios is that the level of GHG accumulated in the atmosphere until 2014 (PPM, Figure 3), as a consequence of $\mathrm{CO}_{2}$ emissions by the current high-income countries since the industrial revolution, is quite high (GHG = 441 ppm, equivalent to $83 \%$ of the threshold of $530 \mathrm{ppm}$ ). Therefore, the room for change is rather limited, an example that responsibilities are common but (very) differentiated. 
The main differences between these two scenarios are in energy and environmental indicators. The combined effort to reduce the rate of economic growth and increase the rate of growth of energy efficiency generates a significant reduction in global $\mathrm{CO}_{2}$ and per capita emissions (Figures 5 and 6). In fact, in 2036, $\mathrm{CO}_{2}$ emissions per capita under the COP21 scenario are $27.8 \%$ lower than the per capita emissions of the $\mathrm{BaU}$ scenario, while total $\mathrm{CO}_{2}$ emissions are $27.3 \%$ lower.

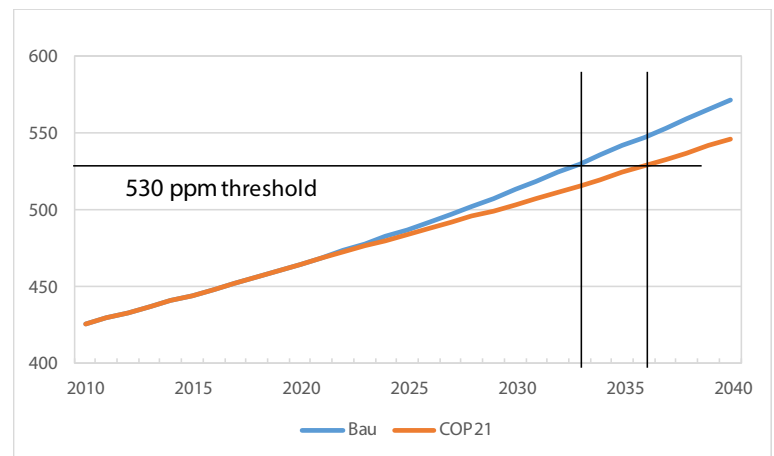

Figure 4. GHG concentration (ppm).

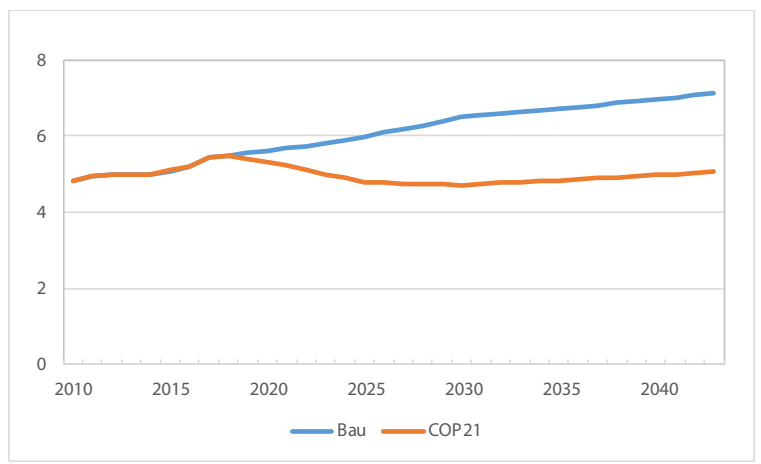

Figure 5. $\mathrm{CO}_{2}$ per capita emissions (tons per capita). 


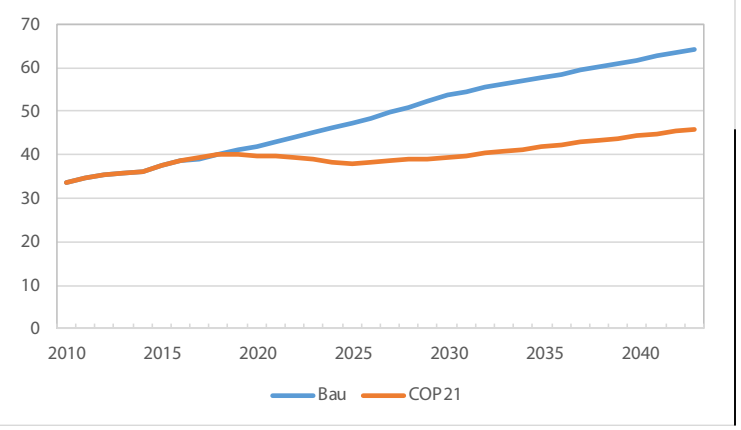

Figure 6. $\mathrm{CO}_{2}$ emissions (Gt).

On the other hand, Table 9a,b shows that, to meet the commitments of COP21, efforts to increase energy efficiency are of great magnitude. For example, according to our econometric estimates, were countries to reduce their economic growth to what is assumed for this scenario, energy efficiency growth should increase $1.5 \%$ in all countries to fulfil the emissions reductions commitment. That is, high-income countries should increase their energy efficiency growth 2.5 times, medium-high and low income countries should double their energy efficiency, and medium-low income countries should increase it by $53 \%$. On the other hand, the last two graphs show that the effort to slow down economic growth and increase energy efficiency must be permanent, i.e., it should go beyond 2030. Otherwise, $\mathrm{CO}_{2}$ and $\mathrm{GHG}$ emissions will immediately resume their growing trends.
Even assuming that global $\mathrm{CO}_{2}$ emissions stabilize at a certain value, for instance the value of 38.0 Gigatons from 2025, thermodynamics would imply that the flow would be absorbed by the good sinks (forests) or bad ones (oceans and soil, increasing the oceans acidity) or would be accumulated in the atmosphere (accentuating the greenhouse effect and climate change). The planet would not reach a stationary state in terms of emissions (when total emissions are absorbed by sinks), but rather would see $\mathrm{CO} 2$ concentration in the atmosphere rising over time.

\section{Results by Income Group}

Figure $7 \mathrm{a}, \mathrm{b}$ presents $\mathrm{CO}_{2}$ emissions per capita and total $\mathrm{CO}_{2}$ emissions for the four income groups under the Business as Usual scenario.

There is a big difference in $\mathrm{CO}_{2}$ emissions in per capita terms among 
the four groups. The relation of higher income resulting in higher emissions is maintained, however the gap between higher income and upper middle income countries is closed from 2030 onwards, according to our simulation. On the other hand, the gaps among upper middle income countries, lower middle

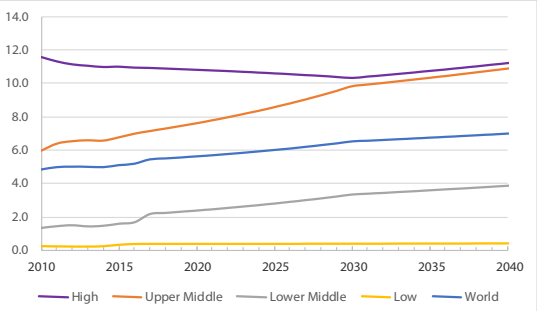

(a) $\mathrm{CO}_{2}$ emissions per capita income and low income not only remain, but even grow over time. Low income countries, however, are characterized by very low levels of $\mathrm{CO}_{2}$ emissions per capita. The final outcome is that the growth in per capita emissions at world level is $1.3 \%$ per year.

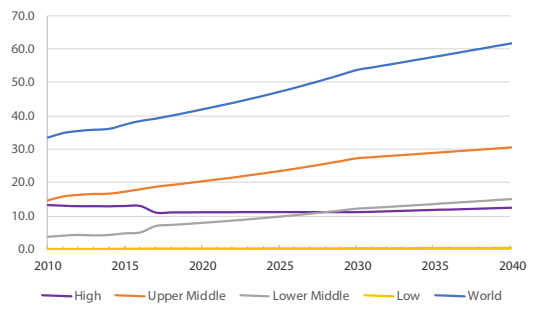

(b) $\mathrm{CO}_{2}$ emissions (Gt)

Figure 7. $\mathrm{CO}_{2}$ emissions per income group. $\mathrm{BaU}$ scenario.

Global $\mathrm{CO}_{2}$ emissions by income group show the effect of population upon emissions per capita, as the different groups have different levels of population. Upper middle income group, which includes China, shows the combined effect of emissions per capita, population and population growth, with the result that this group has $49 \%$ of total emissions. High income countries represent $24 \%$ of global emissions and lower middle income countries account for $21 \%$. Despite the similar share in emissions, high income countries only have about $40 \%$ of the population of lower middle income countries. Low income countries account for only $0.7 \%$ of global emissions.

Figure $8 \mathrm{a}, \mathrm{b}$ presents $\mathrm{CO}_{2}$ emissions per capita and total $\mathrm{CO}_{2}$ for the four income groups under the COP21 scenario.

Figure 8a shows the effects of the Intended Nationally Determined Contributions. The main efforts fall upon high income countries, which should almost halve their emissions, although they are still above the world's average emissions. Upper middle income countries, despite the reduction in the growth path for emissions, would become the group with higher emissions per capita. Lower mid- 
dle income and low income countries, despite maintaining their trend in the growth of emissions, would have lower than the average emissions per capita. The global average remains almost stable, keeping the average for the period 20102015, that is, 5.0 tons per capita.

Including population into the analysis shows the net effect on high income countries, which would see a reduction in total emissions. Upper middle income and lower middle income countries, however, would increase their emissions $1 \%$ and $4.3 \%$, respectively. The impact of low income countries would be even more reduced than in the $\mathrm{BaU}$ scenario, accounting for only $0.4 \%$ of global emissions, on average.

\section{Estimated Toxic Income}

Mean toxic income. Under the assumptions of BaU scenario, at the critical time $t^{*}=2033$, the mean value for toxic income would be $Y_{p c}^{*}=14,208$ (in constant 2010 USD). For the COP21 scenario, the critical period is $t^{*}=2036$ and the mean of the toxic income decreases slightly to a $Y_{p c}^{*}=13,433$ (in constant 2010 USD). That is, a reduction of only $5.4 \%$ (complete results can be seen in Appendix B). Figure 9 shows that GDP per capita during the whole period of the simulation is lower in the COP21 scenario than in the BaU scenario. This result comes from the assumptions made regarding economic growth. The economic growth rate for high income countries is reduced because global GDP per capita is also reduced. This reduction, however, is small, at $5.4 \%$, due to inequality in the distribution of income.

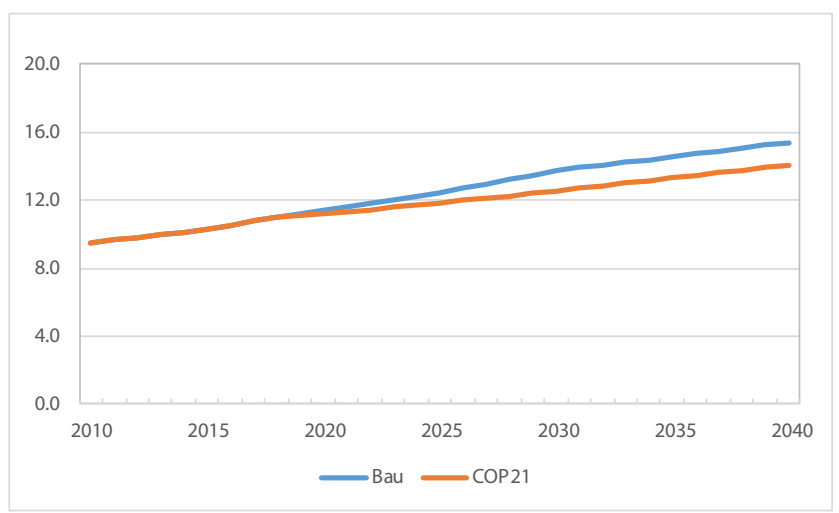

Figure 9. Toxic income (World per capita GDP) (thousand constant 2010 USD). 
Toxic income distribution. The quency graph, and as a probability denwhole per capita toxic income (GDP) sity function in Figures 10 and 11 . distribution is presented as a relative fre-

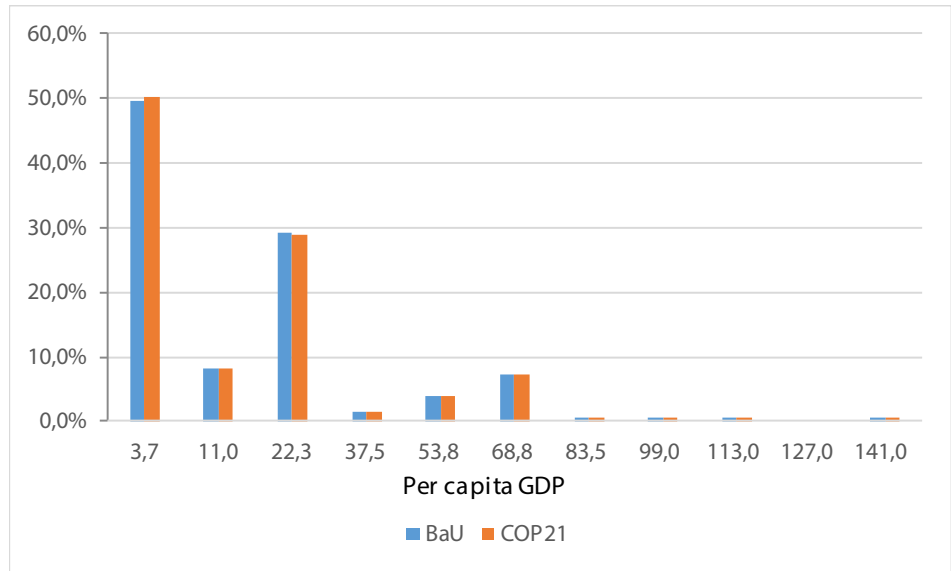

Figure 10. Toxic income (World per capita GDP) frequency.

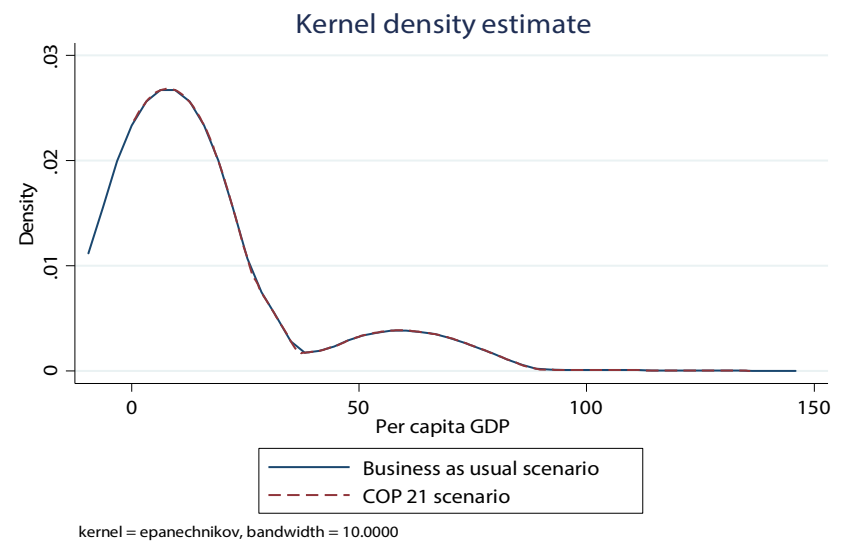

Figure 11. Toxic income (World per capita GDP) density function (the probability density function was estimated by using the "twoway kdensity" Stata command) 
In relation to toxic income distribution, there are small differences between the BaU scenario and the COP21 scenario in the relative frequency and the probability density function.

It is worth mentioning that, in the period between 2014 and 2033 or 2036, income inequality is reduced. The explanation is the deceleration observed in both high income countries and upper middle income countries combined with the increase in the growth rate for lower middle income countries and low income countries. The Gini coefficient goes from 0.6225 in 2014 to 0.5613 in 2033 (BaU scenario) and 0.5602 in 2036 (COP21 scenario).

\section{Historical Responsibilities Related to Toxic Income}

We defined toxic income as the level of per capita income that would generate levels of GHG emissions incompatible with the maintenance of climate change under control. Under this framework, which would bethecommon but differentiated responsibilities that havedrivenincometo becometoxic?

The initial concentration level for GHG (PPMO in Figure 3) is one the factors that determines the critical level of concentration in this analysis. According to the literature [38], between 1750 and 2014 the world emitted 1.5 million Gt of CO2. According to our simulation, in the BaU scenario (2015-2033), cumulated CO2 emissions would total 885 thousand Gt, whereas, under the COP21 scenario (2015-2036), CO2 emissions would be 871 thousand Gt. Under the assumption that GHG emissions are proportional to CO2 emissions, emissions in the critical period $t^{*}$ would be distributed as indicated in Table 10. 
Table 10. (a) Cumulated $\mathrm{CO}_{2}$ emissions, historical period 1751-2014. ( b) Cumulated $\mathrm{CO}_{2}$ emissions.

Simulation period 1751-2014.

\begin{tabular}{|c|c|c|c|c|c|c|c|c|}
\hline \multicolumn{9}{|c|}{ (a) } \\
\hline & \multicolumn{8}{|c|}{ Income Group ( $\left.10^{3} \mathrm{Gt}\right)$} \\
\hline & \multicolumn{2}{|c|}{ High } & Upper Middle & \multicolumn{2}{|c|}{ Lower Middle } & Low & \multicolumn{2}{|l|}{ World } \\
\hline Cumulated emissions & \multicolumn{2}{|c|}{872.0} & 423.2 & \multicolumn{2}{|c|}{112.8} & 7.4 & \multicolumn{2}{|c|}{1475.6} \\
\hline \multirow[t]{3}{*}{$\%$ share } & \multicolumn{2}{|c|}{$59.1 \%$} & $28.7 \%$ & \multicolumn{2}{|c|}{$7.6 \%$} & \multirow[t]{2}{*}{$0.5 \%$} & & \\
\hline & \multicolumn{5}{|c|}{ (b) } & & & \\
\hline & \multicolumn{4}{|c|}{ BaU Scenario } & \multicolumn{4}{|c|}{ COP21 Scenario } \\
\hline \multirow[t]{2}{*}{ Income Group } & \multicolumn{2}{|c|}{$2015-2033$} & \multicolumn{2}{|c|}{$1751-2033$} & \multicolumn{2}{|c|}{$2015-2036$} & \multicolumn{2}{|c|}{$1751-2036$} \\
\hline & $10^{3} \mathrm{Gt}$ & $\%$ Share & $10^{3} \mathrm{Gt}$ & $\%$ Share & $10^{3} \mathrm{Gt}$ & \% Share & $10^{3} \mathrm{Gt}$ & $\%$ Share \\
\hline High & 214.9 & $24.3 \%$ & 1086.9 & $46.0 \%$ & 187.6 & $21.5 \%$ & 1059.6 & $45.2 \%$ \\
\hline Upper middle & 436.2 & $49.3 \%$ & 859.4 & $36.4 \%$ & 431.1 & $49.5 \%$ & 854.3 & $36.4 \%$ \\
\hline Lower middle & 179.0 & $20.2 \%$ & 291.8 & $12.4 \%$ & 196.9 & $22.6 \%$ & 309.7 & $13.2 \%$ \\
\hline Low & 6.0 & $0.7 \%$ & 13.4 & $0.6 \%$ & 7.1 & $0.8 \%$ & 14.5 & $0.6 \%$ \\
\hline World & 884.8 & & 2360.4 & & 870.6 & & 2346.2 & \\
\hline
\end{tabular}

Historical responsibilities for $\mathrm{CO}_{2}$ emissions are absolutely differentiated. High income countries are responsible for $59.1 \%$ of cumulated $\mathrm{CO}_{2}$ emissions, whereas the upper middle income group of countries is responsible for $28.3 \%$ of cumulated emissions. Both lower middle income group and low income group combined would represent only $8.1 \%$ of cumulated emissions. The inequality is even more noticeable if we consider that high income countries only represented 16.2\% of world population in 2014.

The resultsforboth simulation scenarios do not differ much. If we add historical data on emissions, the differences are even smaller. For instance, adding historical emissions in the case of the COP21 scenario, the share of cumulated GHG emissions by income group would be the following: $45.2 \%$ for high income countries; $36.4 \%$ for upper middle income countries; $13.2 \%$ for lower middle income countries; and $0.6 \%$ for low income countries.

This very same inequality in the distribution of emissions among income groups can be seen when we compute the average per capita emissions per year (historical plus simulated) for both scenarios, as presented in Table 11. 
Table 11. Average historical and simulated CO 2 emissions per capita per year.

\begin{tabular}{ccccccc}
\hline & \multicolumn{5}{c}{ Income Group $(\mathrm{t})$} \\
\cline { 2 - 6 } & High & Upper Middle & Lower Middle & Low & World \\
\hline BaU scenario1751-2033 & 10.6 & 5.2 & 1.7 & 0.2 & 4.8 \\
COP21 scenario1751-2036 & 9.8 & 4.9 & 1.7 & 0.3 & 4.5 \\
\hline \multicolumn{6}{c}{ Source: [21], Simulation model. }
\end{tabular}

Under the COP21 scenario, which more emissions than a citizen of a lower is the one with less inequality, between middle income country; and 38.5 times years 1751 and 2036, a citizen of a high more emissions than a citizen from a low income country would have emitted incomecountry. twice the amount of $\mathrm{CO}_{2}$ as a citizen of an Table 12 shows the inequality in upper middle income country; 5.8 times income among the different groups.

Table 12. Income inequality among groups of countries.

\begin{tabular}{cccccc}
\hline & \multicolumn{5}{c}{ Income Group (constant 2010 USD) } \\
\cline { 2 - 6 } & High & Upper Middle & Lower Middle & Low & World \\
\hline BaU scenario (2033) & 54.980 & 14.186 & 4.031 & 731 & 14.208 \\
COP21 scenario (2036) & 52.607 & 13.372 & 4.045 & 754 & 13.433 \\
\hline
\end{tabular}

Source: Simulation model.

As in the previous case, a citizen of come country; and 73 times higher than a high income country, under the COP21 scenario, would have an average income in the critical period $t^{*}$ (2036) 4.1 times higher than a citizen from a upper middle income country; 13.6 times higher a citizen from a low income country.

The dynamics of current economic growth generates pollution and social inequality. This is the essence of toxic income at the world level. than a citizen from a lower middle in- 


\section{CONCLUSIONS AND POLICY IMPLICATIONS}

If nothing changes in the midterm, in about 14 years, the threshold for critical concentration in the atmosphere will be reached. This result makes us believe that INDC need to become mandatory commitments for the different countries. The impact of INDC on global $\mathrm{CO}_{2}$ emissions is noticeable. INDC are not mandatory, but voluntary measures. If implemented, the environmental consequences would be very positive. There is a need for combining energy efficiency measures in productive processes with moderation in consumption and in population growth, as well as reducing economic growth. That decrease in growth is what Tim Jackson calls "prosperity without growth" for rich countries [39]: productive restructuring of developed economies towards economic sectors with lower environmental impact. Low-middle income and especially low income countries would still be able to grow, in per capita terms, to guarantee decent living standards for their citizens.

Global responsibilities of developed economies need not only be directed to avoid their own $\mathrm{CO}_{2}$ emissions and mitigating environmental impacts, but also to help to reduce $\mathrm{CO}_{2}$ emissions of the rest of the countries, especially in developing countries, and to improve living conditions in these countries. This can only be possible through scientific and technological cooperation and transfer of technology from the North to the South. This is the least that can be demanded in light of differentiated responsibilities, which are based on the historical contribution of rich countries to current concentration levels of greenhouse gases in the atmosphere.

The analysis shows that, if current trends of population growth, income, emissions per capita and energy efficiency will be maintained, at some point, by 2033, the critical threshold for mean toxic income per capita of $Y_{p c}^{*}=14,208$ (in constant 2010 USD) would be reached. This means that any income level above that value could be considered as toxic income, as it would go hand in hand with $\mathrm{CO}_{2}$ emissions and greenhouse gases concentration levels above 530 ppm, which inevitably would increase global mean temperature threshold above $2^{\circ} \mathrm{C}$.

The distribution of toxic income additionally shows the high level of inequality that characterizes the world (Gini $=0.5602$ ). Combating climate change needs to go hand in hand with fighting income inequality at a world level, giving room for economic development of poorer and more vulnerable countries.

The essence of toxic income is pollution and inequality. 
INDCs presented at the last COP21 in Paris in December 2015 [37], need to become mandatory commitments for the different countries. After 2030, the world will need to enter a path of decreasing global and per capita $\mathrm{CO}_{2}$ emissions that will require a transition of our energy and transport sectors towards the massive use of renewable energies.

In this sense, international agreements on climate change, additional to INDC, should include the proposals under C\&C and apply them, not just to CO2 emissions as proposed in the past, but also to income levels of countries. Countries with income levels above the critical threshold should contract, allowing countries with income levels below the threshold to converge towards that critical value that would avoid temperature rise above $2^{\circ} \mathrm{C}$. The verification of the existence of toxic income opens the discussion about the different strategies to confront climate change.

Technology plays a key role in combating climate change. High income countries have both the technology and the economic means to abate GHG emissions, as well as to introduce adaptation and mitigation measures. On the other hand, poor countries lack the technology or the economic resources to confront this pressing problem. World Bank data [21] shows that R\&D per capita investment in low income and middle income countries was 16.4 times lower than in high income countries. This translates in low levels of knowledge production. Low income and middle income countries had 251 patent applications per million inhabitants, compared to 1118 applications for high income countries in 2016 [21]. Additionally, another explaining factor is the current asymmetry in the international regime for intellectual property rights, that penalizes poor countries that do not have the resources for protecting their inventions, and that do not have access to new technology due to the high costs of the royalties involved [40].

In any case, it is the opinion of the authors that future strategies oriented to reduce emissions need to consider the drop in renewable energy costs and therefore the likelihood that these technologies may represent an ever growing share of the energy mix.

As one can see, the consequences would not fall just on energy or climate policy, but also in pursuing certain levels of equality in the world distribution of income, which would be highly desirable. Future research will focus on the depiction of the convergence scenarios for the different groups of countries.

Author Contributions: F.F. conceived the concept of toxic income; F.F. and R.B. conceived and designed the 
econometric model and the simulation; R.B. conducted the simulation; F.F., R.B., J.R.-M. and P.C. analyzed the data and wrote the paper.

Funding: This research and the APC were funded by the Spanish Ministry of Science and Innovation under the Grant HAR2016-76814-C2-1-P (AEI/ FEDER UE).

Acknowledgments: The authors would like to thank the editor and the anonymous referees for providing relevant comments that improved the paper.

Conflicts of Interest: The authors declare no conflict of interest. The founding sponsors had no role in the design of the study; in the collection, analyses, or interpretation of data; in the writing of the manuscript, and in the decision to publish the results. 


\section{APPENDIX A ECONOMETRIC REGRESSIONS}

\section{Low income countries}

Table A2. Linear model.

\begin{tabular}{ccccccccc}
\hline Country & $\mathrm{R}^{2}$ & $\beta_{0}$ & $\mathrm{y}_{\mathrm{t}}$ & $\mathrm{E}_{\mathrm{t}}$ & $\mathrm{AR}(1)$ & $\mathrm{d}$ & $\mathrm{AIC}$ & $\mathrm{ndat}$ \\
\hline \multirow{2}{*}{ El Salvador } & 0.760 & 0.095 & 0.554 & -0.197 & & 2.656 & -1.005 & 44 \\
& & 0.499 & 11.091 & -4.041 & & & & \\
\hline \multirow{2}{*}{ Guatemala } & \multirow{2}{*}{0.789} & -0.357 & 0.552 & -0.070 & 0.284 & 2.114 & -1.921 & 44 \\
& & -0.830 & 5.905 & -1.304 & 1.907 & & & \\
\hline \multirow{2}{*}{ Indonesia } & 0.931 & 0.191 & 0.699 & -0.138 & 0.312 & 1.627 & -0.898 & 44 \\
& & 0.422 & 6.015 & -0.709 & 4.062 & & & \\
\hline
\end{tabular}

Table A3. Linear spline model.

\begin{tabular}{|c|c|c|c|c|c|c|c|c|c|c|}
\hline Country & $\mathrm{R}^{2}$ & $\beta_{0}$ & $\mathrm{y}_{\mathrm{t} \mid \mathrm{y}_{0}}$ & $\mathrm{y}_{\mathrm{t} \mid \mathrm{y}_{0}}^{\otimes}$ & $E_{t}$ & $\mathrm{AR}(1)$ & & $d$ & $\mathrm{AIC}$ & ndat \\
\hline \multirow{2}{*}{ Bangladesh } & 0.997 & 0.103 & 0.887 & 0.707 & -0.093 & & 0.551 & 1.651 & -7.073 & 43 \\
\hline & & 2.766 & 55.419 & 33.485 & -8.541 & & & & & \\
\hline \multirow{2}{*}{ Bolivia } & 0.868 & -1.444 & 2.042 & 0.928 & -0.158 & & 1.466 & 2.121 & -1.042 & 44 \\
\hline & & -2.297 & 4.537 & 8.135 & -7.702 & & & & & \\
\hline \multirow{2}{*}{ Cote d'Ivoire } & 0.651 & -0.823 & 1.069 & 0.040 & -0.049 & & 1.527 & 1.573 & -2.106 & 44 \\
\hline & & -3.856 & 4.893 & 0.569 & -1.485 & & & & & \\
\hline \multirow{2}{*}{ Honduras } & 0.792 & 0.521 & 0.069 & 1.202 & -0.037 & & 1.498 & 2.354 & -1.520 & 44 \\
\hline & & 0.815 & 0.107 & 10.440 & -0.243 & & & & & \\
\hline \multirow{2}{*}{ Mongolia } & 0.796 & 4.920 & 1.647 & 4.705 & -2.713 & & 2.229 & 2.186 & 3.055 & 30 \\
\hline & & 3.418 & 1.792 & 8.090 & -3.673 & & & & & \\
\hline \multirow{2}{*}{ Morocco } & 0.993 & 0.728 & 0.696 & 0.515 & -0.173 & & 2.508 & 1.892 & -3.798 & 44 \\
\hline & & 6.363 & 51.437 & 12.178 & -8.261 & & & & & \\
\hline \multirow{2}{*}{ Myanmar } & 0.801 & 0.078 & 0.928 & 0.572 & -0.158 & & 0.347 & 1.667 & -4.331 & 44 \\
\hline & & 3.987 & 6.368 & 6.081 & -5.037 & & & & & \\
\hline \multirow{2}{*}{ Pakistan } & 0.994 & 0.226 & 1.380 & 0.654 & -0.340 & & 1.014 & 2.017 & -5.075 & 44 \\
\hline & & 2.865 & 35.227 & 2.700 & -5.973 & & & & & \\
\hline \multirow{2}{*}{ Tunisia } & 0.988 & 0.988 & 0.919 & 0.540 & -0.346 & & 2.110 & 2.136 & -2.840 & 44 \\
\hline & & 2.432 & 11.115 & 23.957 & -5.186 & & & & & \\
\hline \multirow{2}{*}{$\begin{array}{c}\text { Egypt, Arab } \\
\text { Rep. }\end{array}$} & 0.975 & 0.954 & 0.760 & 1.021 & -0.246 & 0.388 & 1.513 & 1.922 & -1.803 & 44 \\
\hline & & 1.741 & 2.635 & 14.121 & -2.669 & 3.442 & & & & \\
\hline \multirow{2}{*}{ India } & 0.997 & 0.269 & 2.478 & 1.362 & -0.584 & 0.242 & 0.657 & 1.833 & -4.773 & 44 \\
\hline & & 3.500 & 17.217 & 17.105 & -7.541 & 2.353 & & & & \\
\hline \multirow{2}{*}{ Sri Lanka } & 0.964 & 0.140 & 0.455 & 0.345 & -0.107 & 0.618 & 1.947 & 2.485 & -3.567 & 44 \\
\hline & & 1.894 & 6.736 & 7.876 & -2.925 & 3.938 & & & & \\
\hline
\end{tabular}

Lower middle income countries 
Upper middle income countries

Table A4. Linear model.

\begin{tabular}{cccccccc}
\hline Country & $\mathrm{R}^{2}$ & $\beta_{0}$ & $\mathrm{y}_{\mathrm{t}}$ & $\mathrm{E}_{\mathrm{t}}$ & $\mathrm{d}$ & $\mathrm{AIC}$ & ndat \\
\hline \multirow{2}{*}{ Argentina } & 0.872 & 2.470 & 0.333 & -0.253 & 2.449 & -0.952 & 44 \\
& & 6.893 & 14.607 & -2.880 & & & \\
\hline \multirow{2}{*}{ Ecuador } & 0.753 & 0.857 & 0.645 & -0.247 & 1.743 & 0.314 & 44 \\
& & 1.460 & 8.749 & -3.610 & & & \\
\hline \multirow{2}{*}{ Mexico } & 0.934 & 4.185 & 0.368 & -0.589 & 1.742 & -1.040 & 44 \\
& & 12.263 & 19.784 & -11.287 & & & \\
\hline
\end{tabular}

Table A5. Linear spline model.

\begin{tabular}{ccccccccccc}
\hline Country & $\mathrm{R}^{2}$ & $\beta_{0}$ & $\mathrm{y}_{\mathrm{t} \mid \mathrm{y}_{0}}$ & $\mathrm{y}_{\mathrm{t} \mid \mathrm{y}_{0}}^{\otimes}$ & $\mathrm{E}_{\mathrm{t}}$ & $\mathrm{AR}(1)$ & $\mathrm{y}_{0}$ & $\mathrm{~d}$ & AIC & ndat \\
\hline \multirow{2}{*}{ Costa Rica } & \multirow{2}{*}{0.936} & 0.446 & 0.274 & 0.046 & -0.078 & & 6.606 & 2.348 & -1.954 & 44 \\
& & 1.303 & 11.236 & 1.913 & -2.841 & & & & & \\
\hline \multirow{2}{*}{ Panama } & 0.848 & 0.896 & 0.545 & 0.292 & -0.304 & & 6.523 & 2.308 & -0.538 & 44 \\
& & 5.389 & 10.185 & 7.270 & -8.757 & & & & & \\
\hline \multirow{2}{*}{ South Africa } & 0.896 & 4.491 & 1.996 & 0.828 & -3.181 & & 6.217 & 2.045 & 0.492 & 44 \\
& & 3.174 & 7.541 & 7.983 & -17.026 & & & & & \\
\hline \multirow{2}{*}{ Turkey } & 0.997 & 1.845 & 0.459 & 0.324 & -0.327 & 0.513 & 8.332 & 1.967 & -2.544 & 55 \\
& & 6.061 & 29.324 & 17.580 & -9.248 & 3.240 & & & & \\
\hline
\end{tabular}


Table A6. Quadratic spline model.

\begin{tabular}{|c|c|c|c|c|c|c|c|c|c|c|c|}
\hline Country & $\mathrm{R}^{2}$ & $\beta_{0}$ & $y_{t \mid y_{0}}$ & $\mathrm{y}_{\mathrm{t} \mid \mathrm{y}_{0}}^{2}$ & $\mathrm{y}_{\mathrm{t} \mid \mathrm{y}_{0}}^{\otimes}$ & $E_{t}$ & $\mathrm{AR}(1)$ & $y_{0}$ & $d$ & AIC & ndat \\
\hline \multirow{2}{*}{ Albania } & 0.895 & 0.181 & 2.784 & -0.446 & 1.149 & -0.749 & & 3.001 & 2.064 & 0.203 & 35 \\
\hline & & 0.182 & 3.186 & -2.203 & 7.376 & -13.06 & & & & & \\
\hline \multirow{2}{*}{ Algeria } & 0.644 & -5.021 & 4.907 & -0.696 & 1.249 & -0.134 & & 4.091 & 2.065 & 0.816 & 44 \\
\hline & & -1.466 & 2.516 & -2.446 & 2.567 & -3.752 & & & & & \\
\hline \multirow{2}{*}{ Botswana } & 0.910 & 4.127 & -1.503 & 0.389 & 0.544 & -0.567 & & 4.011 & 1.835 & -0.412 & 34 \\
\hline & & 3.183 & -1.608 & 2.729 & 5.605 & -3.890 & & & & & \\
\hline \multirow{2}{*}{ Brazil } & 0.938 & 0.734 & 0.806 & -0.037 & 0.266 & -0.395 & & 9.762 & 1.854 & -1.865 & 44 \\
\hline & & 1.317 & 3.918 & -2.836 & 8.088 & -5.648 & & & & & \\
\hline \multirow{2}{*}{ Bulgaria } & 0.931 & -121.8 & 77.278 & -10.73 & 2.716 & -6.991 & & 3.782 & 2.351 & 1.502 & 35 \\
\hline & & -2.318 & 2.610 & -2.582 & 13.685 & -16.77 & & & & & \\
\hline \multirow{2}{*}{ Dominican Republic } & 0.951 & 3.399 & -2.130 & 0.630 & 0.204 & -0.189 & & 3.194 & 1.776 & -1.351 & 44 \\
\hline & & 3.804 & -2.737 & 4.329 & 2.632 & -3.330 & & & & & \\
\hline \multirow{2}{*}{ Gabon } & 0.714 & 35.089 & -7.053 & 0.413 & 0.292 & -0.352 & & 12.131 & 1.985 & 3.506 & 44 \\
\hline & & 1.937 & -1.985 & 2.461 & 1.688 & -2.482 & & & & & \\
\hline \multirow{2}{*}{ Iran, Islamic Rep. } & 0.880 & 9.644 & -2.986 & 0.471 & 0.450 & -0.498 & & 5.964 & 2.525 & 1.938 & 44 \\
\hline & & 1.950 & -1.471 & 2.306 & 2.050 & -9.868 & & & & & \\
\hline \multirow{2}{*}{ Jamaica } & 0.878 & 844.7 & -470.6 & 66.019 & 0.297 & -0.947 & & 3.674 & 1.652 & 0.086 & 44 \\
\hline & & 2.320 & -2.311 & 2.320 & 3.487 & -13.354 & & & & & \\
\hline \multirow{2}{*}{ Jordan } & 0.969 & 4.225 & -0.198 & 0.181 & 0.261 & -0.709 & & 3.349 & 2.540 & -1.434 & $4 \quad 40$ \\
\hline & & 5.463 & -0.367 & 1.816 & 1.416 & -21.15 & & & & & \\
\hline \multirow{2}{*}{ Malaysia } & 0.988 & 2.654 & -0.934 & 0.241 & 0.747 & -0.047 & & 5.500 & 2.380 & 0.228 & 44 \\
\hline & & 2.367 & -2.584 & 5.429 & 19.695 & -0.264 & & & & & \\
\hline \multirow{2}{*}{ Mauritius } & 0.998 & 0.596 & 0.739 & -0.013 & 0.362 & -0.310 & & 6.747 & 2.025 & -3.025 & 539 \\
\hline & & 3.934 & 13.067 & -2.185 & 11.702 & -8.939 & & & & & \\
\hline \multirow{2}{*}{ Paraguay } & 0.891 & 0.720 & -0.173 & 0.142 & 0.332 & -0.172 & & 2.912 & 1.652 & -2.486 & $5 \quad 44$ \\
\hline & & 2.808 & -0.538 & 2.121 & 3.203 & -2.851 & & & & & \\
\hline \multirow{2}{*}{ Peru } & 0.922 & 2.506 & -0.935 & 0.203 & 0.322 & -0.080 & & 4.070 & 2.677 & -2.013 & 34 \\
\hline & & 2.717 & -1.723 & 2.496 & 7.972 & -5.417 & & & & & \\
\hline \multirow{2}{*}{ Thailand } & 0.996 & 0.746 & 0.481 & 0.105 & 0.585 & -0.279 & & 3.969 & 1.828 & -1.911 & 44 \\
\hline & & 5.344 & 2.760 & 3.029 & 14.106 & -3.696 & & & & & \\
\hline \multirow{2}{*}{ China } & 0.944 & 1.296 & 5.599 & -0.906 & 1.569 & -2.807 & 0.788 & 2.259 & 1.456 & -1.058 & 344 \\
\hline & & 3.205 & 6.536 & -3.451 & 16.266 & -10.03 & 4.094 & & & & \\
\hline \multirow{2}{*}{ Colombia } & 0.773 & -0.662 & 1.550 & -0.152 & 0.440 & -0.245 & 0.299 & 4.862 & 1.986 & -2.377 & 44 \\
\hline & & -0.685 & 3.304 & -2.686 & 10.182 & -9.132 & 1.805 & & & & \\
\hline \multirow[b]{2}{*}{ Cuba } & 0.810 & -10.857 & 9.691 & -1.537 & 0.963 & -0.621 & 0.263 & 3.473 & 1.909 & -0.306 & 544 \\
\hline & & -1.282 & 1.756 & -1.730 & 7.750 & -8.657 & 1.720 & & & & \\
\hline
\end{tabular}


High income countries

Table A7. Linear spline model.

\begin{tabular}{ccccccccccc}
\hline Country & $\mathrm{R}^{2}$ & $\beta_{0}$ & $\mathrm{y}_{\mathrm{t} \mid \mathrm{y}_{0}}$ & $\mathrm{y}_{\mathrm{t} \mid \mathrm{y}_{0}}^{*}$ & $\mathrm{E}_{\mathrm{t}}$ & $\mathrm{AR}(1)$ & $\mathrm{y}_{0}$ & $\mathrm{~d}$ & AIC & ndat \\
\hline \multirow{2}{*}{ Israel } & 0.958 & 1.714 & 0.450 & 0.009 & -0.424 & & 25.509 & 1.835 & 0.798 & 44 \\
& & 2.027 & 25.738 & 0.234 & -5.058 & & & & & \\
\hline \multirow{2}{*}{ Oman } & 0.666 & 9.153 & -0.150 & 2.163 & -0.066 & & 15.473 & 2.275 & 4.825 & 44 \\
& & 2.265 & -0.537 & 6.245 & -2.058 & & & & & \\
\hline \multirow{2}{*}{ Trinidad and Tobago } & 0.975 & 17.319 & 0.013 & 2.085 & -2.459 & & 7.198 & 2.515 & 3.622 & 44 \\
& & 2.274 & 0.012 & 24.748 & -6.239 & & & & & \\
\hline \multirow{2}{*}{ United Kingdom } & 0.962 & 14.051 & 0.076 & 0.310 & -0.846 & & 34.442 & 1.748 & 0.245 & 55 \\
& & 82.263 & 4.944 & 7.320 & -13.792 & & & & & \\
\hline \multirow{2}{*}{ Uruguay } & 0.928 & 2.838 & 0.329 & 0.053 & -0.403 & & 9.439 & 2.068 & -1.548 & 44 \\
& & 23.158 & 15.428 & 3.085 & -19.476 & & & & & \\
\hline \multirow{2}{*}{ Hong Kong SAR, China } & 0.970 & 1.992 & 0.411 & 0.173 & -0.278 & 0.513 & 13.191 & 1.914 & 0.149 & 44 \\
& & 1.521 & 4.085 & 11.037 & -9.293 & 3.570 & & & & \\
\hline \multirow{2}{*}{ Netherlands } & 0.929 & 16.579 & 0.156 & 0.254 & -1.476 & 0.207 & 32.148 & 1.979 & 1.114 & 55 \\
\hline \multirow{2}{*}{ Switzerland } & & 17.995 & 8.061 & 10.476 & -16.966 & 2.032 & & & \\
\hline
\end{tabular}


Table A8. Quadratic spline model.

\begin{tabular}{|c|c|c|c|c|c|c|c|c|c|c|c|}
\hline Country & $\mathrm{R}^{2}$ & $\beta_{0}$ & $y_{t \mid y_{0}}$ & $\mathrm{y}_{\mathrm{t} \mid \mathrm{y}_{0}}^{2}$ & $\mathrm{y}_{\mathrm{t} \mid \mathrm{y}_{0}}^{*}$ & $E_{t}$ & $\mathrm{AR}(1)$ & $y_{0}$ & d & AIC & ndat \\
\hline \multirow{2}{*}{ Austria } & 0.958 & 10.542 & 0.350 & -0.002 & 0.081 & -1.214 & & 44.029 & 1.921 & 0.036 & 55 \\
\hline & & 15.634 & 14.285 & -4.544 & 2.191 & -15.016 & & & & & \\
\hline \multirow{2}{*}{ Canada } & 0.963 & 11.256 & 1.290 & -0.016 & 0.508 & -4.495 & & 35.648 & 1.738 & 0.926 & 55 \\
\hline & & 3.627 & 8.292 & -5.467 & 12.441 & -12.682 & & & & & \\
\hline \multirow{2}{*}{ Chile } & 0.958 & 1.943 & 1.705 & -0.134 & 0.385 & -0.831 & & 6.309 & 1.655 & -0.205 & 544 \\
\hline & & 0.847 & 1.762 & -1.472 & 16.860 & -7.380 & & & & & \\
\hline \multirow{2}{*}{ Cyprus } & 0.994 & 3.452 & 0.626 & -0.011 & 0.241 & -0.665 & & 22.560 & 2.403 & -1.545 & 540 \\
\hline & & 11.679 & 15.223 & -8.821 & 29.469 & -28.514 & & & & & \\
\hline \multirow{2}{*}{ Denmark } & 0.970 & 15.441 & 0.122 & 0.002 & 0.156 & -1.112 & & 50.262 & 2.098 & 0.618 & 55 \\
\hline & & 12.761 & 2.060 & 2.232 & 6.115 & -25.735 & & & & & \\
\hline \multirow{2}{*}{ France } & 0.920 & -1.365 & 1.376 & -0.029 & 0.094 & -0.794 & & 31.853 & 0.663 & 1.034 & 55 \\
\hline & & -0.814 & 13.615 & -13.286 & 2.704 & -5.810 & & & & & \\
\hline \multirow{2}{*}{ Greece } & 0.983 & 20.967 & -0.891 & 0.021 & 0.243 & -0.629 & & 15.738 & 2.562 & 0.726 & 55 \\
\hline & & 11.643 & -3.632 & 2.040 & 17.648 & -15.459 & & & & & \\
\hline \multirow{2}{*}{ Japan } & 0.984 & 8.238 & 0.328 & -0.002 & 0.946 & -0.850 & & 44.394 & 2.137 & 0.259 & 55 \\
\hline & & 13.181 & 14.006 & -4.428 & 9.250 & -16.436 & & & & & \\
\hline \multirow{2}{*}{ Korea, Rep. } & 0.996 & 8.486 & 0.440 & 0.067 & 0.450 & -2.072 & & 5.405 & 1.938 & 0.026 & 44 \\
\hline & & 9.252 & 1.261 & 1.496 & 51.835 & -12.215 & & & & & \\
\hline \multirow{2}{*}{ Luxembourg } & 0.938 & -43.958 & 5.207 & -0.074 & 0.321 & -3.170 & & 43.986 & 2.112 & 4.168 & 55 \\
\hline & & -2.227 & 4.665 & -4.721 & 7.387 & -9.767 & & & & & \\
\hline \multirow{2}{*}{ Malta } & 0.983 & 2.711 & 0.615 & -0.008 & 0.230 & -0.486 & & 13.333 & 1.983 & -0.165 & $5 \quad 44$ \\
\hline & & 7.976 & 6.207 & -1.435 & 9.519 & -15.029 & & & & & \\
\hline \multirow{2}{*}{ New Zealand } & 0.886 & 10.302 & -0.206 & 0.010 & -0.074 & -0.672 & & 30.363 & 1.734 & 0.859 & 38 \\
\hline & & 1.431 & -0.390 & 1.020 & -1.127 & -5.208 & & & & & \\
\hline \multirow{2}{*}{ Portugal } & 0.967 & 5.622 & 0.768 & -0.038 & 0.155 & -0.555 & & 12.667 & 1.794 & 0.664 & 55 \\
\hline & & 5.856 & 3.508 & -2.952 & 7.536 & -8.153 & & & & & \\
\hline \multirow{2}{*}{ Singapore } & 0.664 & 6.093 & 1.129 & -0.026 & 0.329 & -0.668 & & 38.117 & 1.905 & 4.048 & 44 \\
\hline & & 2.407 & 6.636 & -6.857 & 2.237 & -2.060 & & & & & \\
\hline \multirow{2}{*}{ United States } & 0.966 & 1.001 & 2.143 & -0.032 & 0.531 & -4.161 & & 31.269 & 1.800 & 0.628 & 55 \\
\hline & & 0.469 & 13.448 & -9.796 & 18.080 & -21.608 & & & & & \\
\hline \multirow{2}{*}{ Australia } & 0.980 & 15.323 & 0.017 & 0.011 & 0.303 & -1.770 & 0.374 & 31.939 & 2.190 & 1.138 & 55 \\
\hline & & 2.377 & 0.038 & 1.339 & 6.550 & -5.857 & 2.779 & & & & \\
\hline \multirow{2}{*}{ Belgium } & 0.920 & 6.111 & 1.283 & -0.025 & 0.145 & -1.710 & 0.533 & 29.914 & 1.925 & 1.187 & 55 \\
\hline & & 1.747 & 4.442 & -4.066 & 4.451 & -12.347 & 6.090 & & & & \\
\hline \multirow{2}{*}{ Finland } & 0.962 & 12.515 & 1.035 & -0.015 & 0.372 & -3.604 & 0.572 & 29.783 & 2.146 & 1.467 & 55 \\
\hline & & 4.434 & 4.110 & -2.651 & 10.338 & -14.972 & 3.370 & & & & \\
\hline \multirow{2}{*}{ Ireland } & 0.987 & 6.944 & 0.444 & -0.003 & 0.304 & -0.853 & 0.215 & 48.672 & 1.963 & -0.686 & 45 \\
\hline & & 21.229 & 17.876 & -7.108 & 9.762 & -30.418 & 1.438 & & & & \\
\hline \multirow{2}{*}{ Italy } & 0.948 & 28.179 & -1.720 & 0.056 & 0.203 & -1.064 & 0.735 & 22.421 & 2.606 & 0.898 & 55 \\
\hline & & 7.205 & -3.829 & 4.341 & 6.749 & -19.555 & 6.321 & & & & \\
\hline Norway & 0.835 & 8.743 & 0.341 & -0.002 & 0.183 & -1.061 & 0.754 & 70.458 & 1.935 & 2.745 & 55 \\
\hline & & 1.604 & 1.486 & -0.862 & 1.970 & -6.057 & 8.580 & & & & \\
\hline Spain & 0.966 & 15.863 & -0.265 & 0.008 & 0.415 & -0.848 & 0.439 & 29.008 & 2.219 & 0.729 & 55 \\
\hline spain & & 11.514 & -2.816 & 3.550 & 3.130 & -15.830 & 3.166 & & & & \\
\hline & 0.955 & -15.067 & 2.484 & -0.047 & 0.200 & -1.266 & 0.443 & 35.239 & 2.020 & 1.228 & 55 \\
\hline den & & -4.588 & 11.399 & -11.995 & 5.843 & -9.595 & 3.312 & & & & \\
\hline
\end{tabular}




\section{APPENDIX B}

Table A9. Simulation results.

\begin{tabular}{|c|c|c|c|c|c|c|c|c|c|c|c|c|c|}
\hline \multirow[b]{2}{*}{ Year } & \multirow[b]{2}{*}{$\begin{array}{l}\text { Popul } \\
\text { Mill }\end{array}$} & \multicolumn{6}{|c|}{ Business as Usual Scenario } & \multicolumn{6}{|c|}{ COP 21 Scenario } \\
\hline & & $\begin{array}{l}\text { PIBpc } \\
\text { US\$ }\end{array}$ & $\begin{array}{c}\mathrm{CO} 2 \mathrm{pc} \\
\mathrm{t}\end{array}$ & $\begin{array}{c}\mathrm{CO} 2 \\
\mathrm{Gt}\end{array}$ & $\begin{array}{c}\text { GHG } \\
\text { Gt }\end{array}$ & $\begin{array}{l}\mathrm{CO} 2 \\
\mathrm{ppm}\end{array}$ & $\begin{array}{l}\text { GHG } \\
\mathrm{ppm}\end{array}$ & $\begin{array}{l}\text { PIBpc } \\
\text { US\$ }\end{array}$ & $\begin{array}{c}\mathrm{CO} 2 \mathrm{pc} \\
\mathrm{t}\end{array}$ & $\begin{array}{c}\mathrm{CO} 2 \\
\mathrm{Gt}\end{array}$ & $\begin{array}{c}\text { GHG } \\
\text { Gt }\end{array}$ & $\begin{array}{l}\mathrm{CO} 2 \\
\mathrm{ppm}\end{array}$ & $\begin{array}{l}\text { GHG } \\
\mathrm{ppm}\end{array}$ \\
\hline 2014 & 7269 & 10.1 & 5.0 & 36.1 & 54.7 & 397.5 & 440.9 & 10.1 & 5.0 & 36.1 & 54.7 & 397.5 & 440.9 \\
\hline 2015 & 7355 & 10.3 & 5.1 & 37.4 & 56.6 & 399.9 & 444.6 & 10.3 & 5.1 & 37.7 & 57.0 & 399.9 & 444.7 \\
\hline 2016 & 7442 & 10.5 & 5.2 & 38.5 & 58.3 & 402.3 & 448.5 & 10.5 & 5.2 & 38.7 & 58.6 & 402.3 & 448.6 \\
\hline 2017 & 7550 & 10.8 & 5.4 & 39.2 & 59.3 & 404.8 & 452.5 & 10.8 & 5.5 & 39.3 & 59.5 & 404.8 & 452.5 \\
\hline 2018 & 7633 & 11.0 & 5.5 & 40.1 & 60.6 & 407.3 & 456.5 & 11.0 & 5.5 & 40.2 & 60.8 & 407.3 & 456.6 \\
\hline 2019 & 7715 & 11.2 & 5.5 & 41.0 & 62.0 & 409.9 & 460.7 & 11.1 & 5.4 & 40.0 & 60.6 & 409.9 & 460.7 \\
\hline 2020 & 7795 & 11.4 & 5.6 & 41.9 & 63.5 & 412.5 & 464.9 & 11.2 & 5.3 & 39.8 & 60.3 & 412.4 & 464.7 \\
\hline 2021 & 7875 & 11.6 & 5.7 & 42.9 & 65.0 & 415.2 & 469.2 & 11.3 & 5.2 & 39.6 & 59.9 & 414.9 & 468.7 \\
\hline 2022 & 7954 & 11.8 & 5.7 & 43.9 & 66.5 & 418.0 & 473.7 & 11.4 & 5.1 & 39.2 & 59.4 & 417.3 & 472.6 \\
\hline 2023 & 8032 & 12.0 & 5.8 & 45.0 & 68.1 & 420.8 & 478.2 & 11.6 & 5.0 & 38.9 & 58.8 & 419.8 & 476.6 \\
\hline 2024 & 8110 & 12.2 & 5.9 & 46.1 & 69.8 & 423.7 & 482.9 & 11.7 & 4.9 & 38.5 & 58.2 & 422.2 & 480.4 \\
\hline 2025 & 8186 & 12.5 & 6.0 & 47.3 & 71.5 & 426.7 & 487.7 & 11.8 & 4.8 & 38.0 & 57.5 & 424.6 & 484.3 \\
\hline 2026 & 8261 & 12.7 & 6.1 & 48.5 & 73.3 & 429.8 & 492.6 & 12.0 & 4.8 & 38.3 & 57.9 & 427.0 & 488.1 \\
\hline 2027 & 8335 & 12.9 & 6.2 & 49.7 & 75.2 & 432.9 & 497.6 & 12.1 & 4.8 & 38.6 & 58.4 & 429.5 & 492.0 \\
\hline 2028 & 8408 & 13.2 & 6.3 & 51.0 & 77.2 & 436.1 & 502.7 & 12.2 & 4.7 & 38.8 & 58.8 & 431.9 & 496.0 \\
\hline 2029 & 8480 & 13.5 & 6.4 & 52.4 & 79.3 & 439.4 & 508.0 & 12.4 & 4.7 & 39.1 & 59.2 & 434.4 & 499.9 \\
\hline 2030 & 8551 & 13.7 & 6.5 & 53.8 & 81.4 & 442.8 & 513.5 & 12.5 & 4.7 & 39.4 & 59.6 & 436.8 & 503.9 \\
\hline 2031 & 8621 & 13.9 & 6.5 & 54.6 & 82.6 & 446.3 & 519.0 & 12.7 & 4.7 & 39.9 & 60.3 & 439.4 & 507.9 \\
\hline 2032 & 8691 & 14.0 & 6.6 & 55.4 & 83.8 & 449.7 & 524.6 & 12.8 & 4.8 & 40.4 & 61.1 & 441.9 & 512.0 \\
\hline 2033 & 8759 & 14.2 & 6.6 & 56.2 & 85.0 & 453.3 & 530.2 & 13.0 & 4.8 & 40.8 & 61.8 & 444.5 & 516.1 \\
\hline 2034 & 8826 & 14.4 & 6.7 & 57.0 & 86.2 & 456.9 & 536.0 & 13.1 & 4.8 & 41.3 & 62.6 & 447.1 & 520.3 \\
\hline 2035 & 8893 & 14.5 & 6.7 & 57.8 & 87.4 & 460.5 & 541.8 & 13.3 & 4.8 & 41.8 & 63.3 & 449.7 & 524.5 \\
\hline 2036 & 8958 & 14.7 & 6.8 & 58.6 & 88.6 & 464.2 & 547.7 & 13.43 & 4.9 & 42.3 & 64.1 & 452.4 & 528.8 \\
\hline 2037 & 9023 & 14.9 & 6.8 & 59.4 & 89.9 & 468.0 & 553.7 & 13.6 & 4.9 & 42.8 & 64.8 & 455.1 & 533.1 \\
\hline 2038 & 9086 & 15.0 & 6.9 & 60.2 & 91.1 & 471.8 & 559.8 & 13.7 & 4.9 & 43.3 & 65.6 & 457.8 & 537.5 \\
\hline 2039 & 9149 & 15.2 & 6.9 & 61.0 & 92.3 & 475.6 & 566.0 & 13.9 & 4.9 & 43.9 & 66.4 & 460.6 & 541.9 \\
\hline 2040 & 9210 & 15.4 & 7.0 & 61.8 & 93.6 & 479.5 & 572.2 & 14.1 & 5.0 & 44.4 & 67.1 & 463.4 & 546.4 \\
\hline
\end{tabular}




\section{REFERENCES}

1. Rogelj, J.; Hare, W.; Lowe, J.; van Vuuren, D.P.; Riahi, K.; Matthews, B.; Hanaoka, T.; Jiang, K.; Meinshausen, M. Emission pathways consistent with a $2{ }^{\circ} \mathrm{C}$ global temperature limit. Nat. Clim. Chang. 2011, 1, 413-418. [CrossRef]

2. Den Elzen, M.; Meinshausen, M. Meeting the $\mathrm{EU} 2^{\circ} \mathrm{C}$ climate target: global and regional emission implications. Clim. Policy 2006, 6, 545-564. [CrossRef]

3. Meinshausen, M.; Meinshausen, N.; Hare, W.; Raper, S.C.B.; Frieler, K.; Knutti, R.; Frame, D.J.; Allen, M.R. Greenhouse-gas emission targets for limiting global warming to 2 degrees $\mathrm{C}$. Nature 2009, 458, 1158-1162. [CrossRef] [PubMed]

4. Rogelj, J.; Hare, B.; Nabel, J.; Macey, K.; Schaeffer, M.; Markmann, K.; Meinshausen, M. Halfway to Copenhagen, no way to $2{ }^{\circ} \mathrm{C}$. Nat. Reports Clim. Chang. 2009, 3, 81-83. [CrossRef]

5. Guivarch, C.; Hallegatte, S. 2C or not 2C? Glob. Environ. Chang. 2013, 23, 179-192. [CrossRef]

6. Climate Change 2013: The Physical Science Basis. Contribution of Working Group I to the Fifth Assessment Report of the Intergovernmental Panel on Climate Change; Stocker, T.F.; Qin, D.; Plattner, G.-K.; Tignor, M.; Allen, S.K.; Boschung, J.; Nauels, A.; Xia, Y.; Bex, V.;
Midgley, P.M. (Eds.) Cambridge University Press: Cambridge,UK, 2013.

7. Boykoff, M.T.; Frame, D.; Randalls, S. Discursive stability meets climate instability: A critical exploration of the concept of "climate stabilization" in contemporary climate policy. Glob. Environ. Chang. 2010, 20, 53-64. [CrossRef]

8. Cleveland,C.J.; Costanza, R.; Hall,C.A.S.; Kaufmann, R. Energy and the United States economy: A biophysical perspective. Science 1984, 225, 890-897. [CrossRef]

9. Cleveland, C.J.; Kaufmann, R.K.; Stern, D.I. Aggregation and the role of energy in the economy. Ecol. Econ. 2000, 32, 301-317. [CrossRef]

10. Csereklyei, Z.; Stern, D.I. Global Energy Use: Decoupling or Convergence? Energy Econ. 2015. [CrossRef]

11. Stern, D.I. A multivariate cointegration analysis of the role of energy in the US macroeconomy. Energy Econ. 2000, 22, 267-283. [CrossRef]

12. Grübler, A.; Nakićenović, N. Decarbonizing the global energy system. Technol. Forecast. Soc. Change 1996, 53, 97-110. [CrossRef]

13. Zhang, Y. Structural decomposition analysis of sources of decarbonizing economic development in China; 1992-2006. Ecol. Econ. 2009, 68, 
2399-2405. [CrossRef]

14. Brizga, J.; Feng, K.; Hubacek, K. Drivers of greenhouse gas emissions in the Baltic States: A structural decomposition analysis. Ecol. Econ. 2014, 98, 22-28. [CrossRef]

15. Steinberger, J.K.; Roberts, J.T. From constraint to sufficiency: The decoupling of energy and carbon from human needs, 1975-2005. Ecol. Econ. 2010, 70, 425-433. [CrossRef]

16. Goldemberg, J.; Tadeo Prado, L. The "decarbonization" of the world's energy matrix. Energy Policy 2010, 38, 3274-3276. [CrossRef]

17. Sonnenschein, J.; Mundaca, L. Decarbonization under green growth strategies? The case of South Korea. J. Clean. Prod. 2016, 123, 180-193. [CrossRef]

18. Steckel, J.C.; Brecha, R.J.; Jakob, M.; Strefler, J.; Luderer, G. Development without energy? Assessing future scenarios of energy consumption in developing countries. Ecol. Econ. 2013, 90, 53-67. [CrossRef]

19. Jägemann, C.; Fürsch, M.; Hagspiel, S.; Nagl, S. Decarbonizing Europe's power sector by 2050-Analyzing the economic implications of alternative decarbonization pathways. Energy Econ. 2013, 40, 622-636. [CrossRef] 20. Sioshansi, F.P. De-carbonizing electricity generation: It won't be easy, cheap, nor enough. Util. Policy 2009, 17,

\section{7-224. [CrossRef]}

21. World Bank. World Development Indicators; The World Bank: Washington, DC, USA; Available online: https:// data.worldbank.org/ (accessed on 24 January 2019).

22. Marcucci, A.; Fragkos, P. Drivers of regional decarbonisation through 2100: A multi-model decomposition analysis. Energy Econ. 2015, 51, 111124. [CrossRef]

23. Bows, A.; Anderson, K. Contraction and convergence: an assessment of the CCOptions model. Clim. Change 2008, 91, 275-290. [CrossRef]

24. Meyer, A. Contraction \& Convergence-The Global Solution to Climate Change; Green Books: Devon, UK, 2000.

25. Meyer, A. Contraction and Convergence. Eng. Sustain. 2004, 157, 3. [CrossRef]

26. Barro, R.J.; Sala-i-Martin, X. Economic Growth, 2nd ed.; The MIT Press: Cambridge, MA, USA, 2003; ISBN 978-0262025539.

27. McGlade, C.; Ekins, P. The geographical distribution of fossil fuels unused when limiting global warming to 2 ${ }^{\circ}$ C. Nature 2015, 517, 187-190. [CrossRef]

28. Falconí, F. Cambio climático y activos tóxicos. ALAl 2014.

29. York, R.; Rosa, E.A.; Dietz, T. STIRPAT, IPAT and ImPACT: analytic tools for unpac- 
king the driving forces of environmental impacts. Ecol. Econ. 2003, 46, 351-365. [CrossRef]

30. Polimeni, J.M.; Mayumi, K.; Giampietro, M.; Alcott, B. The Jevons Paradox and the Myth of Resource Efficiency Improvements; Earthscan: London, UK, 2008; ISBN 978-1-84407-462-4.

31. United Nations; Department of Economic and Social Affairs. Population Division World Population Prospects, the 2015 Revision, Volume I: Comprehensive Tables. ST/ESA/SER.A/379; United Nations Department of Economic and Social Affairs Population Division: New York, NY, USA, 2015.

32. European Environment Agency. European Environment Agency Datasets; European Environment Agency: Copenhagen, Denmark, 2018; Available online: https://www.eea.europa.eu/data-and-maps $/$ data\# $\mathrm{c} 0=5 \& \mathrm{c} 11=\& \mathrm{c} 5=\mathrm{a}-$ II\&_start $=0$.

33. Stern, D.I. Environmental Kuznets Curve. Encycl. Energy 2004, 2, 517525.

34. Novales, A. Econometría; McGraw-Hill: Madrid, Spain, 1988; ISBN 9788476152157.

35. CDIAC. Frequently asked global change questions; CDIAC: Washington, DC, USA, 2015.

36. IPCC. Climate Change 2014: Synthesis Report. Contribution of Working Groups I, II and III to the Fifth Assess- ment Report of the Intergovernmental Panel on Climate Change; IPCC: Geneva, Switzerland, 2014.

37. UNFCCC. Synthesis report on the aggregate effect of the intended nationaIly determined contributions; UNFCCC: Geneva, Switzerland, 2015.

38. Ritchie, H.; Roser, M. CO2 and other Greenhouse Gas Emissions. Available online: https://ourworldindata. org/co2-and-other-greenhousegas-emissions (accessed on 18 April 2019).

39. Jackson, T. Prosperity without Growth: Economics for a Finite Planet; Routledge: London, UK, 2011.

40. Cango, P.; Ramos-Martín, J.; Falconí, F.The Regional Political Economy of Knowledge and Environment. In Regionalism, Development and the Post-Commodities Boom in South America; Vivares, E.A., Ed.; Springer International Publishing: Cham, Switzerland, 2018; pp. 197-215. ISBN 9783-319-62550-8.

(c) 2019 by the authors. Licensee MDPI, Basel, Switzerland. This article is an open access article distributed under the terms and conditions of the Creative Commons Attribution (CC BY) license (http://creativecommons.org/licenses/ by/4.0/). 